\title{
The Land Sparing, Water Surface Use Efficiency, and Water Surface Transformation of Floating Photovoltaic Solar Energy Installations
}

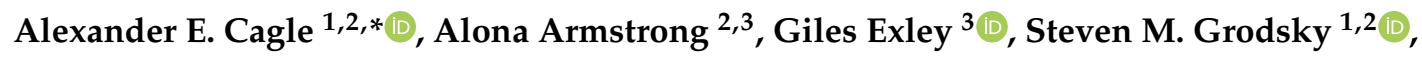 \\ Jordan Macknick ${ }^{4}$, John Sherwin ${ }^{5}$ and Rebecca R. Hernandez ${ }^{1,2}$ (D) \\ 1 Department of Land, Air and Water Resources, UC Davis, Davis, CA 95616, USA; \\ smgrodsky@ucdavis.edu (S.M.G.); rrhernandez@ucdavis.edu (R.R.H.) \\ 2 Wild Energy Initiative, John Muir Institute of the Environment, UC Davis, CA 95616, USA \\ 3 Lancaster Environment Centre, Lancaster University, Lancaster, LA1 4YQ, UK; \\ a.armstrong@lancaster.ac.uk (A.A); g.exley@lancaster.ac.uk (G.E) \\ 4 Scientific Computing and Energy Analysis, National Renewable Energy Laboratory, Golden, CO 80401, USA; \\ Jordan.macknick@nrel.gov \\ 5 Florida Solar Energy Center, University of Central Florida, Orlando, FL 32922, USA; john@fsec.ucf.edu \\ * Correspondence: aecagle@ucdavis.edu
}

Received: 4 September 2020; Accepted: 28 September 2020; Published: 2 October 2020

\begin{abstract}
Floating photovoltaic solar energy installations (FPVs) represent a new type of water surface use, potentially sparing land needed for agriculture and conservation. However, standardized metrics for the land sparing and resource use efficiencies of FPVs are absent. These metrics are critical to understanding the environmental and ecological impacts that FPVs may potentially exhibit. Here, we compared techno-hydrological and spatial attributes of four FPVs spanning different climatic regimes. Next, we defined and quantified the land sparing and water surface use efficiency (WSUE) of each FPV. Lastly, we coined and calculated the water surface transformation (WST) using generation data at the world's first FPV (Far Niente Winery, California). The four FPVs spare 59,555 $\mathrm{m}^{2}$ of land and have a mean land sparing ratio of $2.7: 1 \mathrm{~m}^{2}$ compared to ground-mounted PVs. Mean direct and total capacity-based WSUE is $94.5 \pm 20.1 \mathrm{SD} \mathrm{Wm}^{-2}$ and $35.2 \pm 27.4 \mathrm{SD} \mathrm{Wm}^{-2}$, respectively. Direct and total generation-based WST at Far Niente is 9.3 and $13.4 \mathrm{~m}^{2} \mathrm{MWh}^{-1} \mathrm{yr}^{-1}$, respectively; 2.3 times less area than ground-mounted utility-scale PVs. Our results reveal diverse techno-hydrological and spatial attributes of FPVs, the capacity of FPVs to spare land, and the utility of WSUE and WST metrics.
\end{abstract}

Keywords: energy geography; energy siting; floatovoltaics; floating solar; land use; land sparing; renewable energy; solar energy; photovoltaics

\section{Introduction}

Floating solar photovoltaic installations (FPVs) represent a new type of water surface use, with unique characteristics and water surface impacts relative to other types of water surface uses. Global deployment of FPVs has increased over the past decade, due, in part, to increased demand for renewable energy generation and beneficial land sparing outcomes associated with locating solar photovoltaic (PV) atop pre-existing water bodies [1,2]. Globally, there are over 2.4 gigawatts (GW) of operating FPVs, with an expected annual growth rate of $22 \%$ over the next five years [3]. Deploying solar energy over pre-existing water bodies may spare land for other purposes, such as agriculture and conservation. Additionally, FPVs could contribute significantly to decarbonization targets around the world. For example, the estimated potential for electrical generation from domestic FPVs on 
constructed (i.e., human-made) water bodies within the United States (US) is over $10 \%$ of total US energy demand [4].

Floatovoltaics may at times have custom design and engineering [5]. However, they are increasingly characterized by the attachment of standard PV modules to a buoy-like structure, usually high-density polyethylene pontoons, which are permanently anchored to the bottom or liner of the water body. Electrical equipment, such as inverters and other balance-of-system (BOS) equipment, are typically located onshore and connected to the installation via floating or underwater cables [1]. Additional infrastructure, such as distribution and transmission lines, can also be required for larger installations or in locations in which there is no current distribution network.

While there has been rapid development of FPVs, there has been a lack of research on the technical, hydrological, and spatial attributes of FPVs, specifically compared to ground-mounted PV [1,6,7]. The local recipient environment of ground-mounted PV installations impacts panel performance and lifespan [8], while the construction and operation of ground-mounted PV installations can impact the environment in which it is sited and its associated ecosystem services [2,9-15]. Similarly, the siting of FPVs may impact panel performance as evaporation between the water body surface and the panel lowers ambient panel temperature and disperses additional heat from the panel area [16,17]. Moreover, the design implications for wind-induced cooling of the PV panels can have significant impacts on panel efficiency [18]. Increased humidity and precipitable water on these installations, due to their location over a body of water, however, could lower panel output; humidity has been documented to decrease the performance ratio of PV installations [19].

The configuration and operational deployment of FPVs vary significantly from conventional ground-mounted PVs, making it important to understand the technical, hydrological, and spatial attributes of individual FPV installations to rigorously assess impacts, especially as the technology matures. By collecting information on attributes such as the percent cover of FPVs on water bodies, the floatation devices used to support the installations, panel orientation, and the functional role of the water body, it is possible to increase the accuracy of development projections and theorized electrical generation potential. Currently, FPVs are designed to consolidate the space of the array on the water in order to avoid evaporation of the water body and reduce material costs, thus increasing the FPV packing factor to reduce area use and reduce wind load strain on the installation $[16,20]$. Understanding and maximizing the packing factor of a solar installation, both ground-mounted and FPVs, is critical for reducing Earth surface use for solar energy generation [21].

The lower fixed-angle panel tilt typical of FPVs can have major implications in terms of both generation potential and land use potential. Spencer et al. (2018) modeled the potential of FPVs in a US-wide study and assigned a tilt of $11^{\circ}$, a value derived from current industry practices at that time [4]. Quantifying the actual tilt angle on deployed installations allows for more accurate calculations towards the understanding of the structural integrity, generation capabilities, and evaporative losses of individual FPVs as well as large inventories of FPVs.

The percent coverage of the FPVs on the recipient water body can inform current projections of deployment potential and the types of water bodies suitable for FPV deployment. In their deployment potential predictions for the US, Spencer et al. (2018) reported a median percentage of water surface coverage of $27 \%$, using market data for commercial installations [4]. While this may reflect current median installation trends, the range of percent water surface coverage ranges from $<2 \%$ to $>80 \%$ and there is no significant correlation between water body area and installation coverage $[4,22]$. Such a large range of surface coverage exists due to the fact that many FPVs are typically determined by point-of-use power needs such as peak power demand of a site, other water body uses, and grid capacity constraints [1].

By further understanding the relationship of water body surface coverage with FPVs, installations can be optimized to create more beneficial techno-hydrological synergies between the installation and the body of water [23]. Understanding the selection of individual FPV sites and the extent of use of water surfaces may provide, in part, insight into just decision making of FPV development and its 
realizable generation potential [24]. A standardized framework for quantifying these attributes also confers an empirical understanding of the role of FPVs in meeting the United Nations Sustainable Development Goals (SDGs) [22], notably in aligning clean energy (SDG 7) and land-water interfacing targets (SDG 14 and 15) [25].

Understanding the siting impacts and geography of renewable energy is of increasing importance as energy demand increases globally and tensions between land uses grow due to factors such as agricultural use and forest and wildlife conservation [26-28]. Additionally, these spatial relationships between FPV systems and the water body can have impacts on the techno-hydrological impacts, local ecological interactions, and local ecosystem services. By understanding the different spatial attributes of FPVs, such as the system's roundness and eccentricity, it is possible to further quantify and identify exactly how these systems interact with the surrounding environments.

Shape metrics, such as the roundness, compactness, and eccentricity of an object, allow for a more comprehensive understanding of the various impacts that FPVs may have on the water body and associated environmental and ecological systems. An example of these impacts is how the covering of a water body with FPV directly impacts the amount of solar radiation reaching the water's surface, in turn affecting water quality parameters such as surface water temperature and evaporation [22]. The roundness of both the water body and FPV system could also have significant effects on the surface flow of water across a water body. Due to the taut mooring of FPV installations to the ground, the system directly interferes with surface water flow patterns and thus the compactness and shape of the installation may play an important role in the dynamics of surface water movement.

FPV may also disrupt the thermal regime of the recipient water bodies, altering stratification strength, length, and mixed depth due to perturbations to incoming solar radiation and wind flow across the water surface $[6,22]$. Consequently, the impact of FPV is highly uncertain and will vary between water body types and floatovoltaics designs, including the spatial attributes of the FPV [6]. Diurnal stratification/destratification cycling events are common in ponds as shallow as one meter and play a critical role in oxygen and nutrient mixing within shallow water bodies [29,30]. Stratification generally reduces water quality through reduced mixing and deoxygenation with implications for phytoplankton, nutrient and contaminant loads [29,31]. Additionally, these hydrological shifts, coupled with the reduction in sunlight reaching the recipient water body, can have significant ecological effects for the aquatic and surrounding terrestrial ecology of an FPV [32]. These shifts in environmental and ecological parameters could affect a given water body's compliance to various permits, directives, or environmental impact assessments and thus impacts both pre and post construction must be considered and accounted for in the design and implementation process [33].

Land sparing, as both a research topic and endeavor, has historically been focused on agriculture [34, 35]; however, a land sparing heuristic and analytical framework is increasingly needed for renewable energy given the significant current and projected land takes applicable to energy [26]. Land sparing, within the context of energy for human use, is defined as the substitution of energy development on land for an alternative recipient environment (e.g., constructed water bodies, buildings) such that net land use and land cover change is zero. In this scenario, calculating land sparing requires a priori knowledge (and an assumption based on this allometry) about how much land we would expect to use to host the same amount of capacity as was developed on water.

Alternatively, land sparing can also be achieved with an intensification of energy generation that increases its land use efficiency [36,37]. The use of water bodies as a recipient environment for solar energy infrastructure may be particularly attractive considering its potential for land sparing [2]. For example, [38] found that solar energy development within the built-environment and on salt-affected land, contaminated land, and constructed bodies of water of the Great Central Valley could spare $15 \%$ $\left(8415 \mathrm{~km}^{2}\right)$ of the region's land for other uses, including agriculture and conservation [38]. This could be of increasing value as solar is often seen in competition to agricultural land uses [39]. As no study to date has quantified the land sparing potential of individual operating FPVs, we demonstrate its calculation in this study using observations of attributes from operating FPVs. 
To assess the performance of FPV installations, including impacts on the environment, and compare performance to other energy generation technologies, it is important to first develop a standardized framework of metrics, specifying terms and units. There has been increasing research attempting to quantify relationships between conventional ground-mounted solar energy and land use from regional to global scales, yet due to heterogeneous and non-uniform accounting metrics, it can be difficult to compare data across studies [40-42]. For example, the same metric terms are commonly used to represent both capacity and generation of a facility but with different units, leading to confusion as to what parameter is ultimately being referred to. Standardizing metrics and units to describe FPVs may not only avoid similar issues within FPV research in the future, but also confers a clear pathway for translatable and comparable findings across generation technology types when exploring various renewable and fossil fuel generation options.

Deployment of FPVs has grown rapidly but understanding of their impacts and means to quantify their characteristics has not kept pace. Consequently, the aim of this study is to develop a standardized framework of metrics to quantify the land sparing and resource use efficiencies of FPVs. Our first objective is to compare the techno-hydrological and spatial (e.g., surface area, roundness) attributes of four FPVs spanning different climatic regimes and water body types across the United States (Windsor, California [CA]; Oakville, CA, Walden, Colorado [CO], and Orlando, Florida [FL]), including at the world's first non-experimental FPV at Far Niente Winery (Oakville, CA; Daly 2019). Next, our second objective is to define and quantify the land sparing $\left(\mathrm{m}^{2}\right)$ of each FPV and the land sparing ratio, comparing the area $\left(\mathrm{m}^{2}\right)$ of terrestrial land spared for every $\mathrm{m}^{2}$ of water surface covered directly by FPV per unit of electricity generation between terrestrial and aquatic-based PV installations. Lastly, our third objective is to coin and develop a set of water surface use efficiency (WSUE) and water surface transformation (WST) metrics for FPVs, applicable to capacity- and generation-based FPV data, respectively. We demonstrate the calculation and utility of these metrics using data from our study sites. This study seeks to provide empirical insight into the diverse applications of FPVs and properties of their recipient water bodies. Importantly, our study provides a standardized framework of metrics to calculate and compare the land sparing and resource use efficiencies of FPVs, which can be employed to quantify environmental impacts on constructed bodies of water as well as for meeting goals related to renewable energy generation and sustainability.

\section{Methods}

\subsection{Site Selection}

We identified several prospective FPV sites for study across the United States within the following climates: a humid subtropical site in Florida; a subarctic/boreal site in Colorado; and two warm summer/Mediterranean sites in California. These sites are also at a range of elevations, ranging from 29 to $2455 \mathrm{~m}$ above sea level. Specifically, the Oakville, CA FPV is located within a vineyard in California's Napa Valley. The valley itself is between the Mayacamas and Vaca mountain ranges, creating a climatic signature unique from areas both to the east and west of Napa Valley [43]. While the Windsor, CA FPV exhibits similar climatic trends to the Oakville, CA FPV, the Windsor FPV is within a highly developed and urban land use. The Orlando, FL FPV has the lowest elevation at $29 \mathrm{~m}$ above sea level and is surrounded by a highly developed and urban land use. Finally, the Walden, CO FPV is in the north park basin of the Rocky Mountain range and is surrounded by low development land use, streams, and grasslands [44]. All four FPVs are located on human-constructed and managed functional freshwater bodies. This distribution was dictated by the existence of FPV but also access to sites and data on the performance and operation of the FPV where partnerships could be granted. We developed research partnerships with Far Niente Winery (Oakville, CA), Ciel et Terre (Windsor, CA), the City of Walden (Walden, CO), and the Orlando Utilities Commission (Orlando, FL), which conferred logistical and data access to their respective FPV sites. 


\subsection{Collection of Climatic Attributes}

Accurate climatic data for all four sites in this study is critical to the understanding of the overall environment of the chosen FPV systems. To gather the most detailed information on both current and historic climatic conditions at the sites, precipitation and temperature data were collected from the PRISM climate group AN81m dataset [45]. The AN81m dataset has been chosen as it utilizes all the available stations within the PRISM network and focuses on best estimation within the conterminous U.S [46]. Monthly precipitation and temperature values were calculated by averaging daily records of each month from the period 2005-2019. Monthly standard deviations for both temperature and precipitation were calculated using the average monthly values from the same time interval (2005-2019).

\subsection{Collection of Technological and Hydrological Attributes of FPVs}

PV is characterized by diverse technical and design modularity, thus, understanding the type and design of panels selected for FPVs may reveal critical technical limitations and opportunities, including those related to cell/panel efficiency, sizing, and expected degradation. We collected information on solar panel type used on each installation through communications with current facility managers. Panel efficiencies and sizing were identified through manufacturer-reported values [47-50]. The choice of PV panels was determined by the individual FPV owner at the time of each FPV's construction as a result of market availability and the current pricing of panels as opposed to strictly maximizing efficiency.

Floating device system and tilt angle specifications for the Oakville, CA site were provided by the current system manager; the floating system was custom-designed for that specific site. The additional three sites (Walden, CO, Windsor, CA, and Orlando, FL, USA) all utilize the same Hydrelio ${ }^{\circledR}$ system manufactured by Ciel et Terre. Specifications for these installations, including tilt angle, were collected through Ciel et Terre-reported values [51]. The water body depth was provided by the current site managers for three of the four sites (Oakville, CA, USA, Walden, CO, USA and Orlando, FL, USA).

\subsection{Collection of Spatial Attributes of Water Bodies}

To measure relationships between the surface area of an FPV installation and its recipient waterbody, we used imagery of the four sites from Google Earth Pro (version 7.3.2.5776; 64 bit) and measured features of interest using the polygon and ruler tools. We measured the major and minor axis of the waterbody by iteratively finding the longest distance within the waterbody polygon and the longest perpendicular $\left(90^{\circ}\right)$ distance to the major axis (Figure $1 \mathrm{~b}$ ). We measured the perimeter and surface area of each body of water by manually outlining the perimeter of the waterbody using the polygon tool. To account for the daily and seasonal variation of water body surface areas [52,53], we measured the object perimeter, convex perimeter, major axis, minor axis, and surface area of each body of water in fall (1 September-30 November), winter (1 December-28 February), spring (1 March-31 May), and summer (1 June-31 August) of the most recent image available for each season (Table A1). Direct FPV area was calculated by using imagery of the four sites from Google Earth Pro (version 7.3.2.5776; 64 bit) and measuring features of interest using the polygon and ruler tools. Previous studies have demonstrated that a RMSE of under $60.9 \mathrm{~cm}$ is achieved when the distance between specific features within an image on Google Earth are measured using the installed polygon and ruler tools [54,55]. The object perimeter and convex perimeter of each water body were then calculated as an average of these measurements (Figure 1a). Here, convex perimeter is defined as the convex hull that encloses an object and excludes local irregularities [54]. The object perimeter, convex perimeter, and major and minor axes were then used to calculate the spatial metrics compactness, roundness, and eccentricity:

$$
\text { Compactness }=\frac{4 \pi \cdot \operatorname{Area}(m)}{(\text { Object Perimeter }(m))^{2}}
$$




$$
\begin{gathered}
\text { Roundness }=\frac{4 \pi \cdot \operatorname{Area}(m)}{(\text { Convex Perimeter }(m))^{2}} \\
\text { Eccentricity }=\frac{\text { Minor Axis }(m)}{\text { Major Axis }(m)}
\end{gathered}
$$
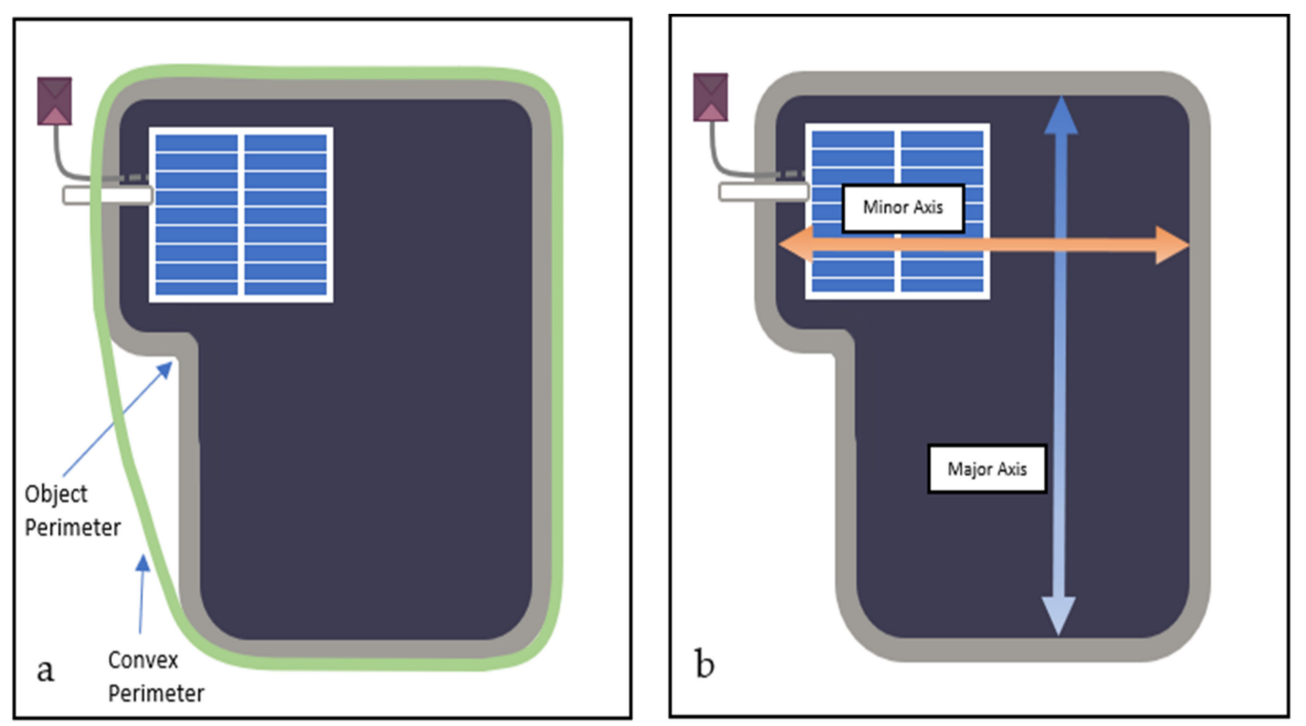

Figure 1. Graphical representation of perimeters and distances used to calculate shape metrics for FPVs: (a) the convex perimeter for a recipient water body and the object perimeter; (b) the major and minor axes of a water body used to calculate eccentricity.

\subsection{Calculation of Land Sparing}

Land sparing requires a priori knowledge (and an assumption based on an allometry) on how much land we would expect to use to host the same amount of energy capacity that was developed on water using a land use efficiency metric (Equations (1) and (4)). Here, we use the allometry, $35.1 \mathrm{~W} \mathrm{~m}^{-2}$, for a ground-mounted installation of $20 \mathrm{MW}$ or greater [9]. As FPVs often construct balance-of-system (BOS; e.g., mounting rack, inverters) and other infrastructure (e.g., roads, gravel paths) on land near the FPVs, we subtract the on-shore footprint (i.e., surface area) from the land spared. For the four sites in this study, this on-shore BOS includes mounting racks, inverters, and floating electrical wiring connecting the FPV to land-based components. We observed Google Earth Pro (version 7.3.2.5776; 64 bit) imagery from before and after FPV construction and found no new roads, gravel paths, or other major infrastructural components added solely for the four FPVs in this study. On-shore BOS and other infrastructure at the Far Niente Winery site support both the FPV and the adjacent ground-mounted PV installation which is has a capacity $1.5 x$ that of the floating array. Therefore, we multiplied the footprint of the on-shore BOS $\left(20.2 \mathrm{~m}^{2}\right)$ at this site by 0.50 to properly allocate BOS associated just with the FPV. This is a conservative allocation given the FPV supplies approximately $40 \%$ of total PV capacity between the two sites. For all other sites, the total footprint of any shore BOS and other infrastructure was subtracted from the land sparing $\left(\mathrm{m}^{2}\right)$. Shore-based BOS in this study does not include distribution or transmission infrastructure as all the sites had been developed intentionally with the knowledge that this infrastructure was pre-existing and could be used for the given FPVs. We then calculated a land sparing ratio (LSR) that relates the area $\left(\mathrm{m}^{2}\right)$ of terrestrial land spared for every $\mathrm{m}^{2}$ of water surface covered directly by FPV as pertaining to installed capacity (Equation 5).

$$
\text { Land Sparing Ratio }(L S R)=\frac{\text { Nameplate Capacity of FPV }(W)}{\text { Land use ef ficiency of ground }- \text { mounted } P V\left(W^{-2}\right)}-\text { BOS Footprint }\left(m^{2}\right)
$$




$$
\text { Land Sparing Ratio }(\text { LSR })=\frac{\text { Estimated direct land use of ground - mounted PV }\left(\mathrm{m}^{2}\right)}{\text { Direct Land Use of FPV array }\left(\mathrm{m}^{2}\right)}
$$

\subsection{Calculation of Water Surface Use Efficiency (WSUE)}

We define the water surface use efficiency (WSUE) as a metric to quantify the relationship between the nameplate capacity of an FPV and the footprint of the recipient body of water (e.g., $\mathrm{W} \mathrm{m}^{-2}, \mathrm{~kW}$ $\mathrm{m}^{-2}$ ). The direct WSUE is a measure of the relationship between the capacity of an FPV and the area of water directly covered by the FPV from a $90^{\circ}$ view angle (direct FPV footprint $\left[\mathrm{m}^{2}\right]$; Figure $2 \mathrm{~b}$ - see " $i$. ", Equation (6)):

$$
\text { Direct WSUE }=\frac{\text { Nameplate Capacity of FPV }(W)}{\text { Surface area of FPV Array }\left(m^{2}\right)}
$$

The Total WSUE is a measure of the relationship between the capacity (W) or generation (MWh) of an FPV and the total area of the recipient water body on which the FPV is sited (Figure 2b see "ii."):

$$
\text { Total WSUE }=\frac{\text { Nameplate Capacity of FPV }(W)}{\text { Surface area of the Recipient Water Body }\left(m^{2}\right)}
$$

Capacity-based WSUE data are useful for comparisons of FPV infrastructure between two or more proposed PV projects (both land and FPV), estimating water surface area and cost requirements, and in setting water use efficiency targets for new projects. In contrast to capacity-based data, generation-based data provide critical information for more detailed comparisons emphasizing realized generation, especially in revealing differences due to variation in generation over time.
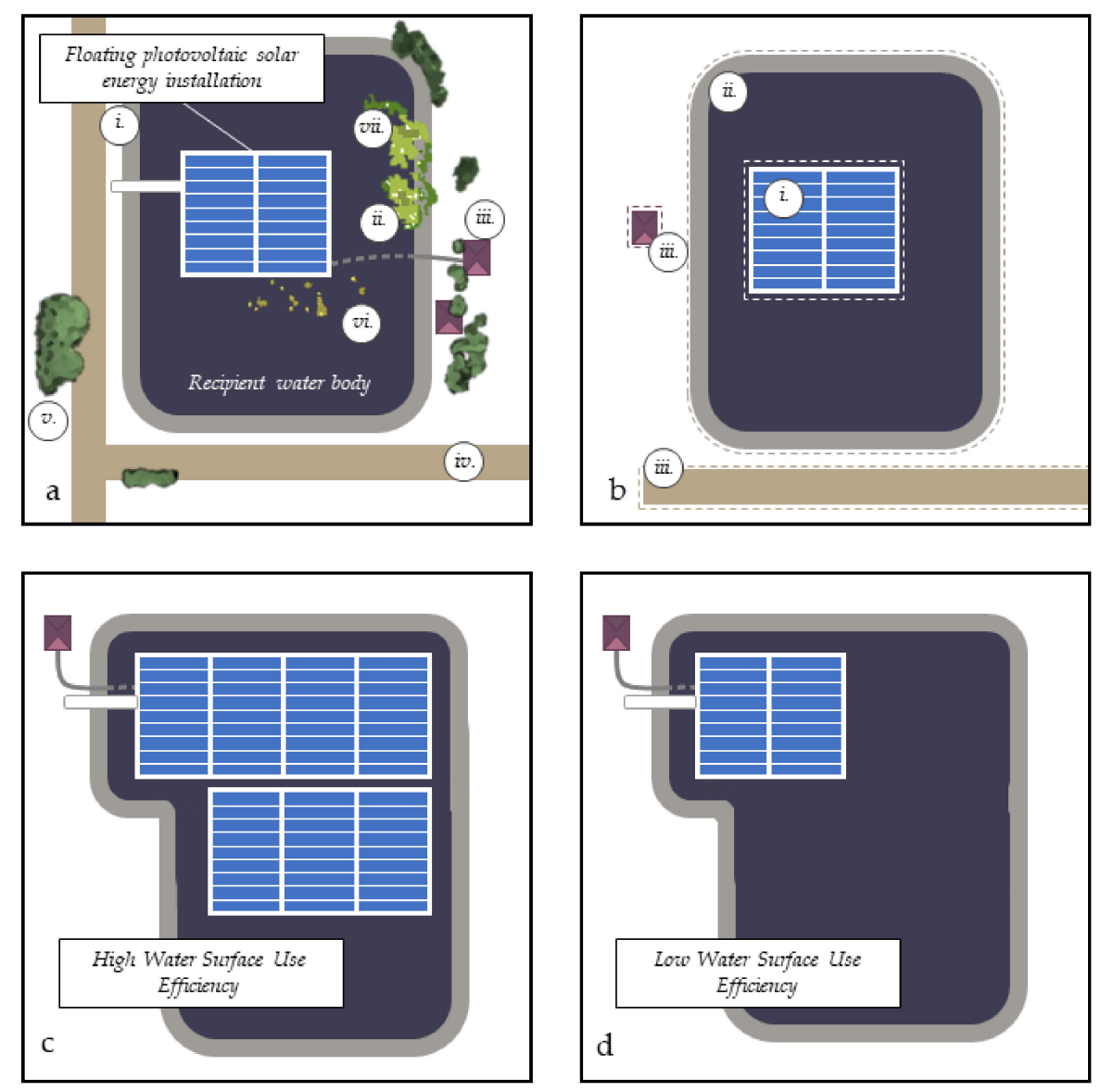

Figure 2. Floating photovoltaic solar energy installations and relationships with their recipient water bodies and land: (a) graphical representation of typical spatial elements of a floating photovoltaic solar 
energy installation (FPV) including the (i.) access dock, (ii.) cable, (iii.) onshore inverters and other on-shore balance-of-system (BOS) and infrastructure including (iv.) access roads; and vegetation, including, (v.) land-based vegetation, (vi.) floating plants, cyanobacteria, submerged macrophytes, and (vii.) emergent vegetation; (b) spatial footprints of an FPV system used to calculate land sparing and water surface use efficiency of FPVs, including the (i.) footprint of a floating photovoltaic solar energy installation, (ii.) footprint of recipient water body, (iii.) footprint of on-shore BOS and infrastructure including the construction of new access roads $\left(\mathrm{m}^{2}\right)$; (c) representation of an FPV with a high water surface use efficiency $\left(\mathrm{W} \mathrm{m}^{-2}\right) ;(\mathbf{d})$ representation of an FPV with a low water surface use efficiency $\left(\mathrm{W} \mathrm{m}^{-2}\right)$.

\subsection{Calculating Generation-Based Direct and Total WST}

We obtained daily generation data for the Oakville, CA FPV from 1 January 2018 to 31 December 2018 and used these data to compute the average capacity factor, direct WST, and total WST. The data were gathered from the six string inverters connected to the FPV. A 14-day period ranging from 2 November 2018 to 16 November 2018 produced no measurable generation due to technical difficulties and thus this time series was excluded from generation calculations. For the remaining 351 days, the data were continuous and complete for one of the inverters; four of the inverters were missing small amounts of data $(n=55)$; and for one inverter, there were 64 missing values. To fill gaps in the data, values from the adjacent inverter were used as a baseline and values were calculated for each inverter as a proportion of installed capacity (all six inverters were identical in technical specifications other than installed capacity). For example, if the malfunctioning inverter had a capacity of $45 \mathrm{~kW}$ compared to the properly functioning inverter's capacity of $50 \mathrm{~kW}$, the daily value was calculated by taking $90 \%$ of the functioning inverter's generation value. The calculated annual generation for the site was thus a sum of all the adjusted inverter's generation for the year. Capacity factor is here defined as the ratio of actual power output of a power producer to the maximum possible rated output of the same power producer. Subsequently, direct WST was calculated by dividing the annual generation by the area of the FPV. Finally, we calculated total WST by dividing the calculated annual generation by the total area of the water body.

$$
\begin{gathered}
\text { Direct WST }=\frac{\text { Surface area of FPV Array }\left(\mathrm{m}^{2}\right)}{\text { Observed Generation of FPV }(\mathrm{MWh})} \\
\text { Total WST }=\frac{\text { Surface area of the Recipient Water Body }\left(\mathrm{m}^{2}\right)}{\text { Observed Generation of FPV }(\mathrm{MWh})}
\end{gathered}
$$

\section{Results}

\subsection{Climatic Attributes of FPVs}

The locations of the four FPVs investigated in this study demonstrate a wide range of operational climates and environments (Figure 1). Across the four sites, average annual daily temperature extremes range from a low of $-33.8^{\circ} \mathrm{C}$ in Walden, $\mathrm{CO}$ to $39.6^{\circ} \mathrm{C}$ in Oakville, $\mathrm{CA}$ (Figure 3a). Average annual precipitation across the four sites ranges from a low of $29.6 \mathrm{~cm}$ in Walden, CO, which is the highest elevation site $(2455 \mathrm{~m})$, to $188.0 \mathrm{~cm}$ in Orlando, FL (Figure 3a), the lowest elevation site $(29 \mathrm{~m})$. The FPVs span three Köppen climatic classifications: warm-summer Mediterranean (Csb), subarctic (Dfc), and humid-subtropical (Cfa). While three (Walden, CO, Windsor, CA, and Oakville, CA) of the four sites demonstrate average annual low temperatures that fall below freezing, only one site (Walden, CO) exhibits consistent annual water body freezing events (Figure 3a). Snowfall occurs at the Walden, CO installation, where PV panels become completely covered with snow for approximately four to five months during the winter season [56].

\subsection{Technohydrological Attributes of FPVs}

FPV nameplate capacity ranges from $31.5 \mathrm{~kW}$ (Orlando, FL) to $1780 \mathrm{~kW}$ (Windsor, CA). The age of systems across the four sites also ranges, as of March 2020, from one year (Windsor, CA) to 12 years (Oakville, CA) (Table 1). The FPVs have a fixed-tilt panel mounting system with either a $12^{\circ}$ panel tilt angle (Windsor, CA, Walden, CO, and Orlando, FL) or a $22^{\circ}$ panel tilt angle (Oakville, CA) (Table 1). All four FPVs use different models of PV panels that range in rated panel efficiency from $12.8 \%$ at the Oakville, CA site to $18.6 \%$ at the Windsor, CA site (Table 1 ). 

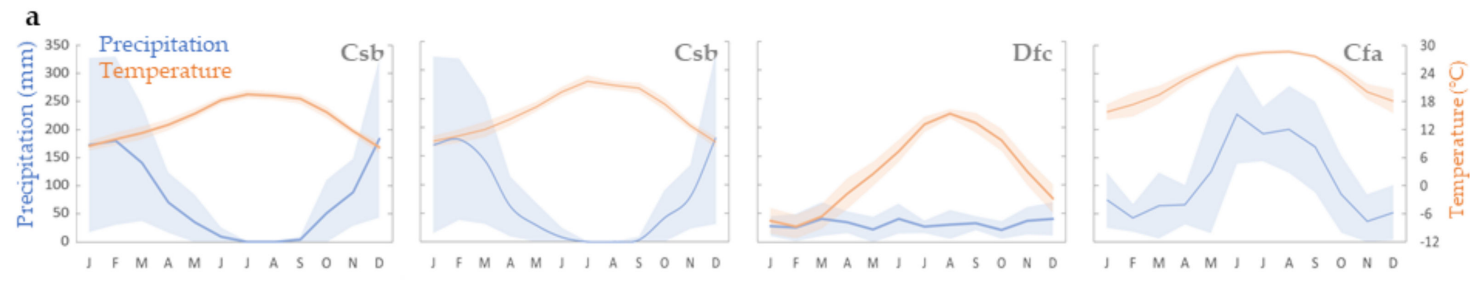

b
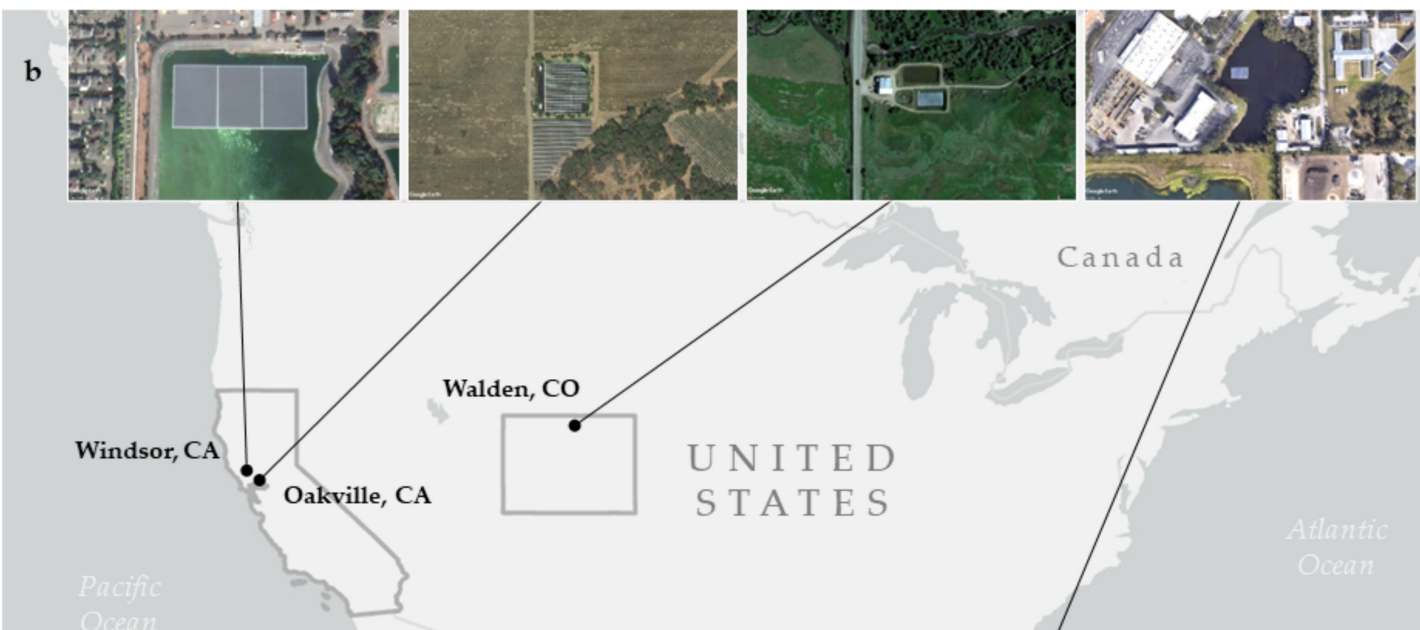

Walden, $\mathrm{CO}$

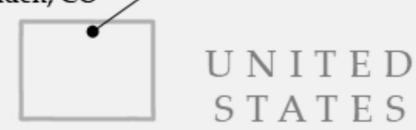

Mexico

Figure 3. Geographical location and climatic regimes of four FPV sites (irrigation pond-Oakville, CA; water treatment holding pond-Windsor, $\mathrm{CA}$; water treatment holding pond-Walden, $\mathrm{CO}$; storm water run-off pond-Orlando, FL) in the United States (US): (a) average temperature (orange) and precipitation (blue) of the four sites (shading represents \pm 1 standard deviation). Data from the PRISM climate group were used for this analysis [45]. The three-letter abbreviations represent the Köppen climate of each site ( $\mathrm{Csb}=$ warm summer Mediterranean, $\mathrm{Dfc}=$ subarctic, $\mathrm{Cfa}=$ humid subtropical); (b) map of the US showing locations of each FPV and a bird's eye view of each site from $304.8 \mathrm{~m}$ elevation.

Table 1. Technological attributes of four floating photovoltaic solar energy installations in the United States.

\begin{tabular}{|c|c|c|c|c|c|}
\hline \multirow{2}{*}{ Technological Attribute } & \multicolumn{4}{|c|}{ Location } & \multirow[b]{2}{*}{ Mean } \\
\hline & Oakville, CA & Windsor, CA & Walden, CO & Orlando, FL & \\
\hline Installation capacity $(\mathrm{kWp})$ & 206 & 1,780 & 74 & 31.5 & 522.8 \\
\hline $\begin{array}{c}\text { Number of PV panels in } \\
\text { installation }\end{array}$ & 994 & 4,959 & 208 & 100 & 1,566 \\
\hline $\begin{array}{c}\text { Age of FPV system as of March } \\
2020 \text { (years) }\end{array}$ & 12 & 1 & 2 & 3 & 4.5 \\
\hline PV panel technology & $\begin{array}{l}\text { Sharp } \\
\text { ND-208U2 }\end{array}$ & $\begin{array}{l}\text { Risen Energy } \\
\text { RSM72-6-360M }\end{array}$ & Jinko 355W & $\begin{array}{c}\text { Renesola } \\
\text { JC315M-315W }\end{array}$ & N/A \\
\hline Panel efficiency & $12.8 \%$ & $18.6 \%$ & $18.3 \%$ & $16.2 \%$ & $16.5 \%$ \\
\hline Floatation device type & $\begin{array}{c}\text { Custom } \\
\text { Manufacture }\end{array}$ & Hydrelio $^{1}$ & Hydrelio $^{1}$ & Hydrelio $^{1}$ & N/A \\
\hline Panel tilt & $22^{\circ}$ & $12^{\circ}$ & $12^{\circ}$ & $12^{\circ}$ & $14.5^{\circ}$ \\
\hline
\end{tabular}

${ }^{1}$ The Hydrelio ${ }^{\circledR}$ floating solar platform is a standardized product manufactured by Ciel et Terre@ [57].

The FPVs in this study are located on freshwater, constructed water bodies. Water inflow and outflow are both extensively managed and controlled at three of the four sites (Oakville, CA, Windsor, CA, and Walden, CO) while the fourth site (Orlando, FL) has naturally fluctuating flow patterns (Table 2). Additionally, the types of water bodies in this study include water treatment holding reservoirs, an irrigation pond, and a stormwater 
run-off pond (Table 2). We determined that the Oakville, CA, Walden, CO, and Orlando, FL water bodies had depths of 3.4, 1.0 and approximately $3.0 \mathrm{~m}$, respectively; however, we were unable to determine the depth of water at Windsor, CA (Table 2).

Table 2. Hydrological attributes of the recipient water bodies of four floating photovoltaic solar energy installations in the United States. The measures of variation represent \pm 1 standard deviations within the dataset. Variance represents \pm 1 standard deviation.

\begin{tabular}{|c|c|c|c|c|c|}
\hline \multirow{2}{*}{ Hydrological Attributes } & \multicolumn{4}{|c|}{ Location } & \multirow[b]{2}{*}{ Mean } \\
\hline & Oakville, CA & Windsor, CA & Walden, CO & Orlando, FL & \\
\hline Managed inputs & yes (1) & yes $(1)$ & yes $(1)$ & no $(0)$ & $0.75 \pm 0.5$ \\
\hline Water body type & Irrigation pond & $\begin{array}{l}\text { Water treatment } \\
\text { holding pond }\end{array}$ & $\begin{array}{l}\text { Water treatment } \\
\text { holding pond }\end{array}$ & $\begin{array}{l}\text { Storm water } \\
\text { run-off pond }\end{array}$ & - \\
\hline Water depth (m) & 3.4 & - & 1 & 3 & $2.5 *$ \\
\hline Water body perimeter $(\mathrm{m})$ & $263 \pm 5.4$ & $1086 \pm 11.1$ & $139 \pm 10.8$ & $589 \pm 40.4$ & $519 \pm 422.7$ \\
\hline
\end{tabular}

* We were unable to locate depth measurements for the Windsor, CA site; mean is based on three sites.

\subsection{Spatial Attributes of FPVs and their Recipient Bodies of Water}

The mean surface area of the recipient water bodies is $21,712 \mathrm{~m}^{2}$. The smallest water body is located at the Walden, CO site $\left(1,346 \pm 34.0 \mathrm{~m}^{2}\right.$ [ \pm 1 Standard Deviation (SD)] $)$ and the largest at the Windsor, CA site $\left(68,121 \pm 2,110 \mathrm{~m}^{2}\right.$ [ $\left.\pm 1 \mathrm{SD}\right]$; Table 2). The mean area of the four FPVs is $5097 \mathrm{~m}^{2}$ with the largest footprint being Windsor, CA (16,184 $\left.\mathrm{m}^{2}\right)$ and the smallest being Orlando, FL (325 $\left.\mathrm{m}^{2}\right)$ (Table 3). We found the site with the most dynamic variation of water surface area to be Oakville, CA (11.3\%) fluctuation). Mean percentage of water surface coverage by the FPVs is $39.8 \pm 31.9 \%$ ( $\pm 1 \mathrm{SD}$ ), ranging from $3.0 \%$ in Orlando, FL to $69.7 \%$ in Oakville, CA (Table 3).

Table 3. Spatial attributes of four floating photovoltaic solar energy installations and their recipient water bodies in the United States. Variance represents \pm 1 standard deviation.

\begin{tabular}{|c|c|c|c|c|c|c|}
\hline \multirow{2}{*}{$\begin{array}{l}\text { FPV System } \\
\text { Components }\end{array}$} & \multirow[t]{2}{*}{ Spatial Attributes } & \multicolumn{4}{|c|}{ Location } & \multirow[b]{2}{*}{ Mean ( \pm 1 SD) } \\
\hline & & Oakville, CA & Windsor, CA & Walden, $\mathrm{CO}$ & Orlando, FL & \\
\hline \multirow[t]{4}{*}{ FPV } & $\begin{array}{c}\text { Surface area of FPV } \\
\text { installation }\left(\mathrm{m}^{2}\right)\end{array}$ & 3,143 & 16,184 & 700 & 359 & $5,097 \pm 7,495$ \\
\hline & $\begin{array}{c}\text { Shore-based land use of } \mathrm{BOS}^{1} \\
\text { (\% of direct FPV area) }\end{array}$ & 0.3 & 0.1 & 0.6 & 1.9 & $0.7 \pm 0.8$ \\
\hline & Packing factor & 0.51 & 0.59 & 0.57 & 0.54 & $0.55 \pm 0.04$ \\
\hline & FPV installation compactness & 0.74 & 0.68 & 0.68 & 0.76 & $0.72 \pm 0.04$ \\
\hline \multirow[t]{4}{*}{ Water Body } & Water body surface area $\left.\left(\mathrm{m}^{2}\right)\right)$ & $4,512 \pm 243$ & $69,452 \pm 2,110$ & $1,110 \pm 34$ & $11,773 \pm 458$ & $21,712 \pm 32,136$ \\
\hline & Water body compactness & 0.823 & 0.741 & 0.722 & 0.426 & $0.68 \pm 0.17$ \\
\hline & Water body roundness & 0.87 & 0.78 & 0.79 & 0.67 & $0.78 \pm 0.08$ \\
\hline & Water body eccentricity & 0.92 & 0.76 & 0.75 & 0.71 & $0.78 \pm 0.09$ \\
\hline $\begin{array}{l}\text { FPV and } \\
\text { Water Body }\end{array}$ & Percent water surface covered & $69.8 \pm 4.0$ & $23.3 \pm 0.7$ & $63.1 \pm 1.9$ & $3.1 \pm 0.1$ & $39.8 \pm 28.7$ \\
\hline
\end{tabular}

${ }^{1}$ BOS: balance of system. This refers to all components separate to the FPV installation itself, namely inverters, transformers, and other electrical equipment typically located on land.

\subsection{Land Sparing, Land Sparing Ratio, and Shore-Based Land Use of FPVs}

We found that three of the four sites were intentionally developed to spare land (Table 4). Across all four sites, we found that mean land sparing is $14,889 \pm 23,969 \mathrm{~m}^{2}( \pm 1 \mathrm{SD})$, with total land sparing across the four sites comprising 58,555 $\mathrm{m}^{2}$, equivalent to approximately 11 American football fields (Table 4). The mean LSR across the four sites is 2.7:1 \pm 0.5 ( $\pm 1 \mathrm{SD}$ ), with the highest LSR at the Windsor, CA site (3.1:1) and the lowest LSR at the Oakville, CA site (1.8:1) (Table 4). Finally, we found on-shore land use of BOS to average $0.7 \pm 0.8 \%$ ( \pm 1 SD) of the total FPV footprint with the smallest on-shore land use at the Windsor, CA site ( $0.1 \%$ of total FPV area) and the largest on-shore land use at the Orlando, FL site (2.1\% of total FPV area) (Table 3). 
Table 4. The land sparing, land sparing ratio (LSR), water surface use efficiency (WSUE), and water surface transformation (WST) of four FPV installations in the United States. Variance represents \pm 1 standard deviation.

\begin{tabular}{cccccc}
\hline \multicolumn{7}{c}{ Location } \\
\hline Resource Use Metric & Oakville, CA & Windsor, CA & Walden, CO & Orlando, FL & Mean ( \pm 1 SD) \\
\hline FPV sited to spare land & yes & yes & yes & no & - \\
Land sparing $\left(\mathrm{m}^{2}\right)$ & 5,859 & 50,702 & 2,104 & 891 & $14,889 \pm 23,969$ \\
Land sparing Ratio $(\mathrm{LSR})\left(\mathrm{m}^{2}: \mathrm{m}^{2}\right)$ & $1.9: 1$ & $3.1: 1$ & $3.0: 1$ & $2.7: 1$ & $2.7: 1$ \\
Direct WSUE $\left(\mathrm{W} \mathrm{m}^{-2}\right)$ & 65.5 & 110 & 105.7 & 96.9 & $94.5 \pm 20.1$ \\
Total WSUE $\left(\mathrm{W} \mathrm{m}^{-2}\right)$ & 45.7 & 25.6 & 66.7 & 2.7 & $35.2 \pm 27.4$ \\
Direct WST $\left(\mathrm{m}^{2} \mathrm{MWh}^{-1} \mathrm{yr}^{-1}\right)$ & 9.3 & - & - & - & - \\
Total WST $\left(\mathrm{m}^{2} \mathrm{MWh}^{-1} \mathrm{yr}^{-1}\right)$ & 13.4 & - & - & - & - \\
\hline
\end{tabular}

\subsection{The Water Surface Use Efficiency (WSUE) of FPVS}

We found that the FPV's average is $94.5 \pm 20.1 \mathrm{~W} \mathrm{~m}^{-2}( \pm 1 \mathrm{SD})$ in direct WSUE across the four sites (Table 4). The newest site, Windsor, CA, has the greatest direct WSUE $\left(110.0 \mathrm{~W} \mathrm{~m}^{-2}\right)$ and the oldest FPV in Oakville, CA, has the lowest direct WSUE $\left(65.5 \mathrm{~W} \mathrm{~m}^{-2}\right.$ ) (Table 4; Figure $\left.4 \mathrm{~b}\right)$. Total WSUE averaged $35.2 \pm 27.4 \mathrm{~W} \mathrm{~m}^{-2}( \pm 1 \mathrm{SD})$, with the greatest WSUE observed at the Walden, CO FPV $\left(66.7 \mathrm{~W} \mathrm{~m}^{-2}\right)$ and the lowest at the Orlando, FL FPV (2.7 $\mathrm{W} \mathrm{m}^{-2}$ ) (Table 4; Figure $4 \mathrm{~b}$ ). The total WSUE for each site averages $35.2 \pm 27.4 \mathrm{~W} \mathrm{~m}^{-2}$ ( $\pm 1 \mathrm{SD}$ ) (Table 4 ). We found the site with the lowest WSUE to be Orlando, FL $\left(2.7 \mathrm{~W} \mathrm{~m}^{-2}\right)$ and the site with the greatest total WSUE to be Walden, CO (66.7 $\mathrm{W} \mathrm{m}^{-2}$ ) (Figure $4 b$ ).

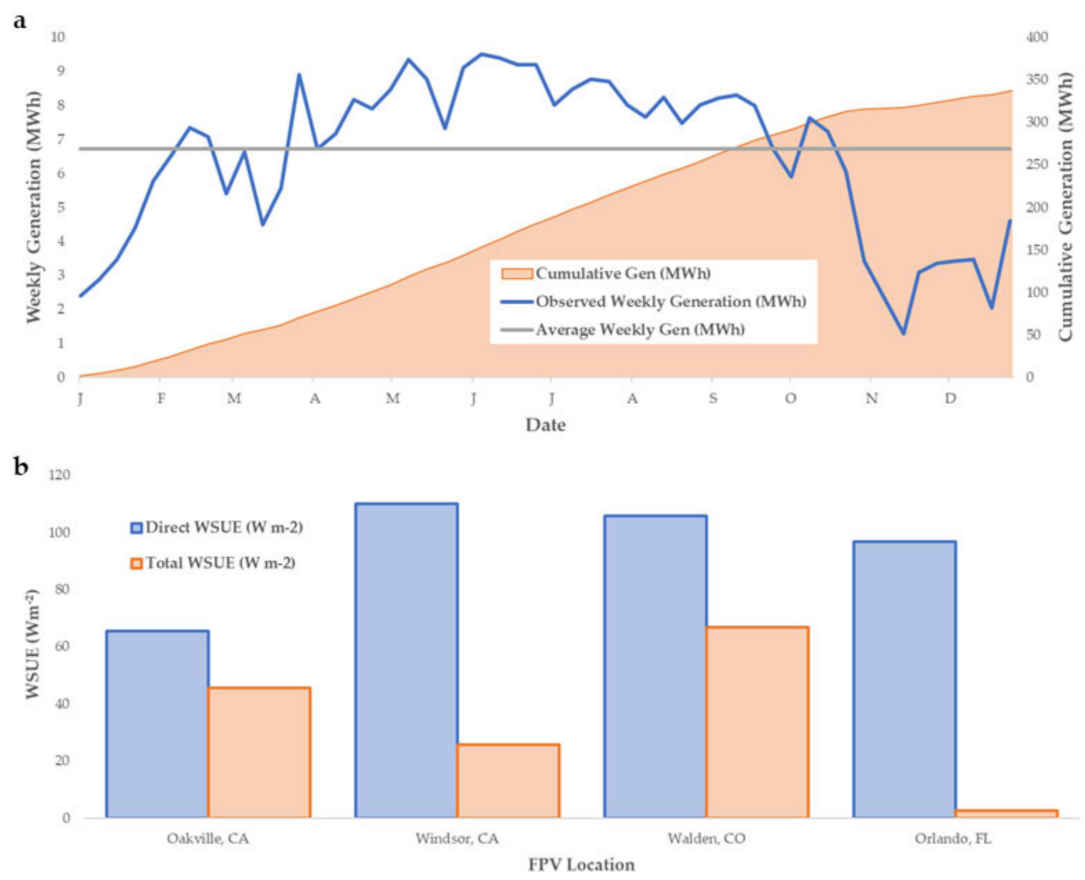

Figure 4. The capacity and generation attributes of four operational FPV installations in the US. (a) The observed weekly generation (MWh) profile (blue line) for the Far Niente (Oakville, CA) FPV installation from 1 January 2018 to 31 December 2018, the observed cumulative generation (orange polygon) in 2018, and the mean weekly generation (grey line); all units in MWh. (b) The direct water surface use efficiency $\left(\mathrm{W} \mathrm{m}^{-2}\right)$ of each site based on nameplate capacity $(\mathrm{W})$ and surface area $\left(\mathrm{m}^{2}\right)$ of the array.

\subsection{Generation-Based Water Surface Transformation (WST)}

Annual generation for the Far Niente Winery (Oakville, CA) FPV was 338.01 MWh in 2018 (Table 4; Figure 4a), with a mean capacity factor of 0.19. Weekly, average generation was 6.6 MWh (Figure 4a). Using these data, we found that the direct and total WST at Far Niente Winery was 9.3 and $13.4 \mathrm{~m}^{2} \mathrm{MWh}^{-1} \mathrm{yr}^{-1}$, respectively (Table 4). 


\section{Discussion}

Photovoltaic solar energy development has, in many places, been emphasized on land, where increasing studies have recognized the importance of understanding synergies and conflicts between technological and environmental outcomes, especially those related to the efficient use of land resources [2,58]. Given the relatively nascent stage of technological innovation for FPVs, understanding attributes and resource use efficiencies of FPVs early in their development transition globally may increase capacity for achieving mutually reinforcing technological and environmental outcomes $[59,60]$.

In this study, we provide an empirical framework to understand resource use relationships between FPVs and water bodies, including the extent to which siting decisions spare land resources and impact water body surfaces. Embodied within this framework, our novel metrics, including standardized terms and units, e.g., water surface use efficiency $\left(\mathrm{W} \mathrm{m}^{-2}\right)$ and water surface transformation $\left(\mathrm{m}^{2} \mathrm{MWh}^{-1} \mathrm{yr}^{-1}\right)$, successfully confer quantitative insight into the local resource use of individual FPVs. However, as we demonstrate, such metrics can also inform questions related to cumulative siting impacts of fleets of FPVs across diverse landscapes and continents.

\subsection{Technohydrological and Spatial Attributes of FPVs}

The four sites in this study demonstrate a wide range of environments and modalities in which FPV installations can and do operate. FPVs in this study ranged by orders of magnitude in nameplate capacity, age of system, and number of panels. Additionally, FPVs in this study have PV panels with either a multicrystalline or monocrystalline structure, with maximum efficiencies $(18.6 \%$ ) of up to $7 \%$ less than industry maximum efficiencies [61]. FPVs in this study are floated on three different types of constructed water bodies: actively managed irrigation ponds, water treatment reservoirs, and unmanaged stormwater run-off ponds. Other studies further demonstrate the diversity of FPV applications on hydroelectric power reservoirs, natural lakes, lagoons, and even in certain marine settings $[16,62,63]$. Specifically, hydroelectric dam reservoirs have demonstrated great potential for FPV deployment $[62,64]$.

Quantifying spatial attributes of FPVs and their recipient water bodies poses unique challenges due to their dynamism over time $[65,66]$. Not only are surface areas of constructed water bodies more dynamic than land footprints (e.g., parking lots), they may also be more dynamic than natural lakes. This is because water levels on many FPVs are actively managed via inflows/outflows for industrial and agricultural activities (e.g., irrigation), varying significantly throughout the year and even within a $24 \mathrm{~h}$ period. Many constructed water bodies have sloped shorelines and/or embankments; thus inflows/outflows can therefore alter water body surface areas and, consequently, calculations of WSUE and WST [67]. We found that a single snapshot in time was insufficient to accurately capture the water body surface area of our four FPV water bodies, which varied over time (2016-2018) by as much as $11.3 \%$ (Oakville, CA). Thus, we caution that WSUE and WST data can only be interpreted within the context of the available temporal observations of water body surfaces.

This underscores the need for high-spatiotemporal-resolution data for the surface area of smaller water bodies [68-70]. Downing et al. (2006) found that millions of smaller lakes, ponds, and impoundments, previously unmapped, dominate the global surface water and are a significant albeit, underappreciated component (>3\%) of Earth's "terrestrial" land surface [71]. Smaller water bodies, such as farm impoundments, are increasing in number over time, and have greater surface area dynamism than larger lakes, further underscoring the importance of accurate geospatial datasets for assessing resource use, impacts, and the technical potential of FPVs [71,72]. We found the water body at the Walden, CO, FPV to be both more shallow $(<2 \mathrm{~m})$ and smaller in surface area $(2000<$ $\mathrm{m}^{2}$ ) than the minimum criteria for water bodies included in a technical potential study of FPV in the US [4]. This demonstrates opportunities to increase the accuracy of such modeling efforts and the need for better geospatial data of small water bodies.

The shape of hydrological elements, which may change over time, can modulate technological and environmental outcomes [30,73-75]. We measured the compactness, roundness, and eccentricity of four FPV recipient water bodies. Lower compactness of a water body, which often implies greater shoreline complexity (also known as the 'shoreline development factor'), is positively associated with biodiversity, including aquatic plant communities and fish $[73,76,77]$. All water bodies in our study had similar compactness and were not very eccentric, excepting Orlando, FL $(0.43,0.71)$, which has two distinct lagoons (or bays); one quite irregular in shape. We also found that the water bodies in our study are not round; some had roundness akin to that of an isosceles triangle (0.78), including Windsor, CA (0.78), and Walden, CO (0.79), and the least round is Orlando, FL (0.67). Across broader datasets of FPVs, understanding the shape of the recipient water bodies for FPVs may serve to, in part, identify FPV sites where biodiversity is most likely to intersect with FPV development, especially in 
urban water bodies which serve as critical refugia for biodiversity and support diverse ecosystem services to local communities [78,79].

Understanding the shape of water bodies is necessary to improve models seeking to identify appropriate recipient water bodies for FPV development and mitigate FPV-related technological and environmental risks. For example, a water body with high eccentricity, embodying narrow channels, bottlenecks, and/or lagoons, may have greater actual surface area than is technically or economically feasible for FPVs. Additionally, constructed ponds have greater eccentricity than natural water bodies and therefore responses to water surface use and transformation (e.g., biogeochemical cycling) may not follow expectations of those observed in natural lakes [80]. Additionally, increasing studies of morphometric properties of natural and constructed water bodies show that changes in shape can result from both anthropogenic and natural drivers of change, including increased withdrawals for human use (e.g., irrigation), climate change, drought, or combinations thereof [81-85]. Any of these factors may impact FPV performance directly by compromising the placement of and connections between FPV panels and/or directly altering generation performance. Rising global temperatures and the proliferation of algal blooms on water bodies can also intersect with FPV development, which may present unanticipated risks and/or opportunities for algal bloom mitigation [2,86]. Understanding the magnitude and direction of present and future risks associated with potential FPV sites may serve to support long-term energy security and investments.

The shape of FPVs, and the degree to which they cover water body surfaces, is another key consideration for aligning technical and environmental outcomes, although studies informing shape are limited compared to those available for water bodies. Ribeiro et al. (2016) found that a rectangular shaped ground-mounted PV installation of the same land area will produce approximately $1.4 \times$ greater annual generation than a square-shaped installation, due to a greater number of panels within that footprint [87]. We found that the FPVs were very similar in compactness, ranging from 0.68 to 0.76 . Ultimately, the shape of an FPV may be driven by not only equipment design standards by the FPV manufacturer (compactness did vary across FPVs by Ciel et Terre@), but also sizing optimization to satisfy demand load, water body attributes (shape, water quality, biodiversity), water body co-use needs and values (flood resilience, recreation, education, visual amenity), meter accessibility, and others, which should be further explored [79]. These factors likely also play a role in determining the amount of water surface covered by panels that, unlike compactness, we found varied strikingly across the four FPVs from 3.1 to $69.8 \%$. For example, the $1.78 \mathrm{MW} \mathrm{FPV}$ at Windsor, CA, was sized to meet the electricity demand of the wastewater treatment facility it covers (39.3\%) [88]. Due to these site-specific siting decisions and the abundance of smaller constructed water bodies, current estimations for FPV technical potential (assuming 27\% water surface coverage) may be underestimating the technical potential of FPVs in the US [4].

\subsection{The Land Sparing of FPVS}

Anthropogenic land use and land cover change (LULCC) is a major contributor to global losses of habitat, biodiversity, and carbon sequestration [89-91]. Additionally, the projected rate of land cover change associated with energy development in the US through 2040 is more than twice the historical rate of urban and residential development [26]. Although our study only evaluated four FPV sites, we found that three of the four were sited intentionally to spare land and, in total, spare $59,555 \mathrm{~m}^{2}$ across all four sites. We also developed a novel land sparing ratio (LSR) metric that compares the direct FPV footprint with the equivalent amount of land necessary to produce the same amount of electricity from a ground-mounted PV installation. Our study found the average LSR of four FPVs to be $2.7: 1 \mathrm{~m}^{2}$, meaning that for every $1.0 \mathrm{~m}^{2}$ of installed capacity on water, it would spare $2.7 \mathrm{~m}^{2}$ of land assuming the deployment of a land-based PV system instead of an FPV. By doing so, the value of land sparing is presented in a way that empirically reveals potential land sparing benefits of FPVs; however, we caution that the accuracy of the LSR is limited to these four sites and will improve with its application to larger FPV datasets.

Land sparing may allay increased competition for land between energy development, agriculture, and biological conservation. While FPVs do require on-shore land for the mounting of BOS equipment, such as inverters and transformers, we found that the mean area of on-shore land use is $0.7 \%$ of the total FPV footprint itself and as low as $0.1 \%$ the total FPV footprint at the Windsor, CA FPV. Our study found that on-shore BOS are sited close by-on average $5.8 \pm 1.12 \mathrm{~m}$ from the shoreline-with only the Orlando, FL, BOS components sited more than six m away $(7.2 \mathrm{~m})$. Additionally, at three of the four sites in this study, the BOS is located on previously developed parking lots and access roads.

Land sparing due to FPV development in a rapid energy transition may be beneficial to local communities as well as global efforts seeking to align climate change with SDGs $[1,25]$. In the European Union and other places, renewable energy development has been found to confer large economic benefits, energy security, and food system 
resilience for rural communities [92,93]. Here, renewable energy development may also drive competition for local land uses, augmenting pressure on such communities to urbanize and reducing the land available to balance local conservation efforts, natural resource preservation, and agricultural needs [21]. Urban areas often lack publicly owned and/or cheap, undeveloped land, which is often emphasized for siting large, ground-mounted renewable energy projects. Rural areas, characterized by low population density and large amounts of expansive land, may be increasingly emphasized for the siting of these technologies [21]. The Walden FPV represents an important example of a rural FPV. Here, it serves to reduce municipal costs, increase energy security, and achieve these outcomes on surfaces that do not conflict with local land use values and practices [21,94]. In the US, the electricity generating potential of FPVs has been conservatively calculated to be as much as $10 \%$ of total energy demand and can meet as much as $32 \%$ in some states [4,63]. It is critical, however, when developing state and national implementation strategies for FPV to ensure equitable inclusion of stakeholders in the decision-making process. This is especially important in rural and socio-economically disadvantaged communities, as such populations have often been disproportionately disenfranchised in the local energy decisions that impact them directly $[95,96]$.

Compared to ground-mounted solar energy installations, FPV development is not displacive as on-shore land requirements have arguably negligible impacts on LULCC [2,12,97,98]. However, shorelines are ecologically vulnerable to changes and studies of on-shore impacts from FPV BOS and related infrastructure, even if negligible, are lacking [99,100]. [38] identified $8,415 \mathrm{~km}^{2}$ of land sparing potential for PV development on unconventional surfaces, including managed water bodies, in the Great Central Valley where land needed for food production, urban development, water rights, and conservation collide [38,101]. Further, FPV development may preclude rebound effects associated with other types of land sparing efforts. For example, land sparing in agriculture is often attained through an increased intensity of use on a given area of land, which can paradoxically generate both short- and long-term land use expansion [102,103]. Comparatively, PV systems can be developed on rooftops, contaminated lands, over parking lots, and synergistically co-located with other land uses such as agriculture and livestock ranging in an effort to both increase land sparing and add alternative value streams [2,104,105]. In this light, FPV deployment is just one, albeit promising, modality of solar energy that can spare land in a given landscape.

\subsection{Water Surface Use Efficiency (WSUE) and Water Surface Transformation (WST)}

Water body surfaces, both natural and constructed, have been used and transformed to support human activities, including for energy (e.g., oil rigs, hydroelectric power), recreation (e.g., boats), food (e.g., aquaculture), and even housing [106,107]. Offshore oil rigs can have surface areas of upwards of $8600 \mathrm{~m}^{2}$ [108] and aquaculture farms are commonly greater than $500,000 \mathrm{~m}^{2}$ in area $[109,110]$.

We found that the mean direct WSUE of FPVs (i.e., the nameplate capacity installed per FPV footprint unit of area) is $94.5 \pm 20.1 \mathrm{~W} \mathrm{~m}^{-2}$ and the greatest WSUE we observed at the two most recently constructed FPVs (Windsor, CA, and Walden, CO), suggesting that improvements in direct WSUE via design (e.g., more panels fitting within a unit of area, performance enhancement of shading) may be increasing. We found that the mean total WSUE of FPVs is $35.2 \mathrm{~W} \mathrm{~m}^{-2}$ and that this is in good standing with observations of the land use efficiency of ground-mounted, utility-scale PV solar energy by [9] (35.1 W m ${ }^{-2}$, for installations $\left.>20 \mathrm{MW}\right)$ and by [42] (41.9 $\mathrm{W} \mathrm{m}^{-2}$, for installations $\left.1<\mathrm{MW}<20 ; 34.3 \mathrm{~W} \mathrm{~m}^{-2},>20 \mathrm{MW}\right)$. We caution that our metrics are based on four FPV installations in the US and future studies that include larger, geographically diverse datasets will improve the accuracy of WSUE. The use of capacity-based metrics also allows for the direct comparison of the efficiency of installed capacity on land use across FPVs, with other solar energy systems, and with other energy generation technologies.

The WST $\left(\mathrm{m}^{2} \mathrm{MWh}^{-1} \mathrm{yr}^{-1}\right)$ confers an empirical understanding of the observed generation of an installation in relation to the amount of space it occupies, which, like WSUE, can be compared across different installations and energy types. We found the direct WST of the Far Niente FPV in 2018 to be $9.3 \mathrm{~m}^{2} \mathrm{MWh}^{-1} \mathrm{yr}^{-1}$ and the total WST to be $13.4 \mathrm{~m}^{2} \mathrm{MWh}^{-1} \mathrm{yr}^{-1}$, the former which is two times greater in use efficiency than the land surface of ground-mounted PV systems $\left(21 \mathrm{~m}^{2} \mathrm{MWh}^{-1} \mathrm{yr}^{-1}\right)$ and 17 times greater in use efficiency than wind energy, including spacing between pads $\left(150 \mathrm{~m}^{2} \mathrm{MWh}^{-1} \mathrm{yr}^{-1}\right)$, reported by [111]. [42] found a direct land use for small-scale PV ( $>1 \mathrm{MW},<20 \mathrm{MW}$ ) to be $13 \mathrm{~m}^{2} \mathrm{MWh}^{-1} \mathrm{yr}^{-1}$ and [40] found a direct land use for wind power (although calculated from only two rows of turbines) to range from 30.5 to $82.6 \mathrm{~m}^{2} \mathrm{MWh}^{-1} \mathrm{yr}^{-1}$ due to various wind speed assumptions. These findings suggest that FPVs may generate more electricity per unit area when compared to other renewable energy technologies. However, we caution that our analysis is focused on a single FPV, which was the world's first, and thus encourage future studies applying these metrics to larger, newly 
constructed, and more geographically diverse FPV datasets. It is likely that FPVs with greater panel efficiencies will likely produce greater WST values than those presented in this research.

The terms 'water surface use efficiency' and 'water surface transformation' were purposefully coined to represent relationships between resources and capacity-based and generation-based FPV data, respectively, and to align with the prevailing preference of terminology for describing land-solar energy relationships ('land use efficiency' and 'land use transformation') based on a systematic review of the literature by [112]. The use of differing metrics is not uncommon but drives unnecessary ambiguity across results of similar studies and can hobble the capacity for comparisons, meta-analysis, and projections $[41,113,114]$. For example, similar underlying issues persist in the reporting of water use in which inconsistent terminology and imprecise units can transmogrify reported water consumption in the US by $-50 \%$ to $+270 \%$ [115]. Additionally, [116] found it is imperative to adjust land use-based metrics if and when they no longer fully capture the intended scope of the original metric; as would be the case here for FPVs. The WSUE $\left(\mathrm{W} \mathrm{m}^{-2}\right)$ and WST $\left(\mathrm{m}^{2} \mathrm{MWh}^{-1} \mathrm{yr}^{-1}\right)$ metrics proposed in this study may serve to obviate current and future ambiguity via the intentional selection of words to coin the terms WSUE and WST, clarity of definitions, and uniformity and scalability of units.

\section{Conclusions}

The rapid increase in renewable energy deployment is causing increased competition for land use globally. This study found that floating solar photovoltaic (FPV) installations offer the ability to spare, on average, 2.7 times the area of ground-mounted PV installations on an installed capacity basis. Additionally, we characterized and quantified technical, hydrological, shape, and spatial attributes of four FPV installations in the US. Finally, we coined a set of capacity-based (WSUE) and generation-based (WST) metrics to standardize both current and future quantifications of water surface and PV system performance to allow for transparent reporting from study to study. This set of metrics is critical to understanding the potential impacts of FPVs both in terms of land sparing and water use and environmental and ecological implications. Additionally, these metrics can be used to accurately disseminate land use and water surface use requirements for new FPV projects to policy makers and project stakeholders in a clear and accurate manner. FPVs decrease the need for additional terrestrial land for renewable energy deployment. As FPV gains in popularity, it is critical to communicate the impacts of the installation's technical performance, hydrological impacts, and water surface coverage in a homogenous manner across all future studies.

Author Contributions: Conceptualization, A.E.C. and R.R.H.; methodology, A.E.C. and R.R.H.; formal analysis, A.E.C. and R.R.H.; investigation, A.E.C.; data curation, A.E.C. and G.E.; writing-original draft preparation, A.E.C. and R.R.H.; writing-review and editing, A.E.C., R.R.H., A.A., J.M., S.M.G., G.E., and J.S.; visualization, A.E.C. and R.R.H.; supervision, R.R.H.; project administration, A.E.C. and R.R.H., funding acquisition, R.R.H. and J.S. All authors have read and agreed to the published version of the manuscript.

Funding: Funding for A.E.C., S.M.G., J.S., and R.R.H. is from the U.S. Department of Energy's Office of Energy Efficiency and Renewable Energy (EERE) under the Solar Energy Technologies Office Award Number DE-EE0008746. A.E.C. was funded partially via the John Muir Institute of the Environment Graduate Student Fellowship with funds from the Steindler Endowment, A.A. acknowledges support from the Natural Environment Research Council, UK, for an Industrial Innovation Fellowship (NE/R013489/1). The views expressed herein do not necessarily represent the views of the U.S. Department of Energy or the United States Government.

Acknowledgments: We thank Jeremy Inducil, Teak Hahn, and Louisa Liu for their contributions in preliminary data collection and analysis. We ardently thank our partners who generously made this research possible: Far Niente Winery (Oakville, CA), Ciel et Terre (Windsor, CA), the City of Walden (Walden, CO), and the Orlando Utilities Commission (Orlando, FL). We thank Michele A. Boyd (Program Manager, Strategic Analysis and Institutional Support) and Andrew Dawson (Technology Development Advisor) in the Solar Energy Technologies Office (SETO) at the U.S. Department of Energy (DOE) for their contributions that significantly improved the quality and impact of this research. At SETO, we also thank Zachary Eldredge (Technology Manager/Technology Advisor) and Christopher Anderson (SETO Technical Project Officer) for providing support and feedback that has helped overcome, in part, the many challenges in research associated with the COVID-19 pandemic.

Conflicts of Interest: The authors declare no conflict of interest. 


\section{Appendix A}

Table A1. Measured water body parameters for four sites in the U.S. For each site, parameters were averaged from measurements taken from images across all four seasons to account for seasonal variability in water levels. Additionally, it is noted whether the FPV installation was deployed during the time of the image being taken, as this may have impacts on water surface measurements. Measurements were derived from Google Earth Images [117-132].

\begin{tabular}{|c|c|c|c|c|c|c|}
\hline Location & & Winter & \multicolumn{3}{|c|}{ Season } & Average ( \pm 1 SD) \\
\hline \multirow[t]{6}{*}{$\begin{array}{l}\text { Oakville, } \\
\text { CA }\end{array}$} & Date & $2 / 5 / 2018$ & $3 / 16 / 2016$ & $5 / 20 / 2017$ & 9/1/2018 & \\
\hline & FPV Present/Absent & Present & Present & Present & Present & \\
\hline & Surface Area $\left(\mathrm{m}^{2}\right)$ & 4662.0 & 4580.0 & 4655.0 & 4153.0 & $4512.5 \pm 242.5$ \\
\hline & Perimeter $(\mathrm{m})$ & 268.0 & 264.0 & 263.0 & 255.0 & $262.5 \pm 5.4$ \\
\hline & Major Axis (m) & 93.4 & 88.2 & 92.6 & 88.1 & $90.6 \pm 2.8$ \\
\hline & Minor Axis (m) & 84.5 & 82.3 & 84.0 & 82.5 & $83.3 \pm 1.1$ \\
\hline \multirow[t]{5}{*}{$\begin{array}{l}\text { Windsor, } \\
\text { CA }\end{array}$} & Date & 11/7/2019 & $3 / 28 / 2018$ & $7 / 28 / 2019$ & $10 / 23 / 2019$ & \\
\hline & FPV Present/Absent & Present & Absent & $\begin{array}{c}\text { Partial } \\
\text { Deployment }\end{array}$ & Present & \\
\hline & Convex Perimeter (m) & 1048.0 & 1070.0 & 1067.0 & 1047.0 & $1058 \pm 12.2$ \\
\hline & Major Axis (m) & 391.0 & 401.0 & 400.0 & 393.0 & $396.25 \pm 5.0$ \\
\hline & Minor Axis (m) & 299.0 & 302.0 & 302.0 & 295.0 & $299.5 \pm 3.3$ \\
\hline \multirow[t]{8}{*}{ Walden, CO } & Date & $6 / 18 / 2014$ & 9/17/2015 & $8 / 26 / 2019$ & $9 / 7 / 2016$ & \\
\hline & FPV Present/Absent & Absent & Absent & Present & Absent & \\
\hline & Surface Area $\left(\mathrm{m}^{2}\right)$ & 1103.0 & 1117.0 & 1068.0 & 1150.0 & $1109.5 \pm 34.0$ \\
\hline & Perimeter $(\mathrm{m})$ & 133.0 & 136.0 & 132.0 & 155.0 & $139.0 \pm 10.8$ \\
\hline & Convex Area (m) & 1150.0 & 1172.0 & 1113.0 & $1,266.0$ & $1175.3 \pm 65.2$ \\
\hline & Convex Perimeter (m) & 131.0 & 132.0 & 129.0 & 139.0 & $132.8 \pm 4.3$ \\
\hline & Major Axis (m) & 47.9 & 48.1 & 47.0 & 49.7 & $48.2 \pm 1.1$ \\
\hline & Minor Axis (m) & 35.3 & 35.9 & 34.2 & 38.8 & $36.1 \pm 2.0$ \\
\hline
\end{tabular}

\section{References}

1. World Bank Group; ESMAP; SERIS. Where Sun Meets Water: Floating Solar Handbook for Practitioners; World Bank: Washington, DC, USA, 2019.

2. Hernandez, R.; Armstrong, A.; Burney, J.A.; Ryan, G.; Moore-O’Leary, K.; Diédhiou, I.; Grodsky, S.M.; Saul-Gershenz, L.; Davis, R.; Macknick, J.; et al. Techno-ecological synergies of solar energy for global sustainability. Nat. Sustain. 2019, 2, 560-568. [CrossRef]

3. Cox, M. Floating Solar Landscape. 2019. Available online: https://www.greentechmedia.com/articles/read/ the-state-of-floating-solar-bigger-projects-and-climbing-capacity (accessed on 7 July 2020).

4. Spencer, R.S.; Macknick, J.; Aznar, A.; Warren, A.; Reese, M.O. Floating Photovoltaic Systems: Assessing the Technical Potential of Photovoltaic Systems on Man-Made Water Bodies in the Continental United States. Environ. Sci. Technol. 2018, 53, 1680-1689. [CrossRef] [PubMed]

5. Trapani, K.; Santafé, M.R. A review of floating photovoltaic installations: 2007-2013. Prog. Photovoltaics: Res. Appl. 2014, 23, 524-532. [CrossRef]

6. Armstrong, A.; Page, T.; Thackeray, S.; Hernandez, R.R.; Jones, I.D. Integrating environmental understanding into floatovoltaic deployment using an effects hierarchy and decision trees. Environ. Res. Lett.. Accepted subject to revisions. 
7. Hooper, T.; Armstrong, A.; Vlaswinkel, B. Environmental impacts and benefits of marine floating solar. Sol. Energy. Accepted Subject to Revisions.

8. Darwish, Z.A.; Kazem, H.A.; Sopian, K.; Al-Goul, M.; Alawadhi, H. Effect of dust pollutant type on photovoltaic performance. Renew. Sustain. Energy Rev. 2015, 41, 735-744. [CrossRef]

9. Hernandez, R.R.; Hoffacker, M.K.; Field, C.B. Land-Use Efficiency of Big Solar. Environ. Sci. Technol. 2014, 48, 1315-1323. [CrossRef] [PubMed]

10. Armstrong, A.; Ostle, N.J.; Whitaker, J. Solar park microclimate and vegetation management effects on grassland carbon cycling. Environ. Res. Lett. 2016, 11, 074016. [CrossRef]

11. Tanner, K.; Moore-O'Leary, K.A.; Parker, I.; Pavlik, B.M.; Hernandez, R. Simulated solar panels create altered microhabitats in desert landforms. Ecosphere 2020, 11, 03089. [CrossRef]

12. Grodsky, S.M.; Hernandez, R. Reduced ecosystem services of desert plants from ground-mounted solar energy development. Nat. Sustain. 2020, 1-8. [CrossRef]

13. Randle-Boggis, R.; White, P.; Cruz, J.; Parker, G.; Montag, H.; Scurlock, J.; Armstrong, A. Realising co-benefits for natural capital and ecosystem services from solar parks: A co-developed, evidence-based approach. Renew. Sustain. Energy Rev. 2020, 125, 109775. [CrossRef]

14. Necefer, L.; Wong-Parodi, G.; Small, M.J.; Begay-Campbell, S. Integrating technical, economic and cultural impacts in a decision support tool for energy resource management in the Navajo Nation. Energy Strat. Rev. 2018, 22, 136-146. [CrossRef]

15. Choi, C.S.; Cagle, A.E.; Macknick, J.; Bloom, D.E.; Caplan, J.S.; Ravi, S. Effects of Revegetation on Soil Physical and Chemical Properties in Solar Photovoltaic Infrastructure. Front. Environ. Sci. 2020, 8, 140. [CrossRef]

16. Sahu, A.; Yadav, N.; Sudhakar, K. Floating photovoltaic power plant: A review. Renew. Sustain. Energy Rev. 2016, 66, 815-824. [CrossRef]

17. Liu, H.; Krishna, V.; Leung, J.L.; Reindl, T.; Zhao, L. Field experience and performance analysis of floating PV technologies in the tropics. Prog. Photovoltaics: Res. Appl. 2018, 26, 957-967. [CrossRef]

18. Waterworth, D.; Armstrong, A. Southerly winds increase the electricity generated by solar photovoltaic systems. Sol. Energy 2020, 202, 123-135. [CrossRef]

19. Peters, I.M.; Liu, H.; Reindl, T.; Buonassisi, T. Global Prediction of Photovoltaic Field Performance Differences Using Open-Source Satellite Data. Joule 2018, 2, 307-322. [CrossRef]

20. Ferrer-Gisbert, C.; Gozálvez, J.J.F.; Redón-Santafé, M.; Ferrer-Gisbert, P.S.; Sánchez-Romero, F.-J.; Torregrosa-Soler, J.B. A new photovoltaic floating cover system for water reservoirs. Renew. Energy 2013, 60, 63-70. [CrossRef]

21. Poggi, F.; Firmino, A.; Amado, M. Planning renewable energy in rural areas: Impacts on occupation and land use. Energy 2018, 155, 630-640. [CrossRef]

22. Exley, G.; Armstrong, A.; Page, T.; Jones, I.D. Floating solar panels affect temperature and stratification in lakes. status (unpublished; manuscript in preparation).

23. Santafé, M.R.; Soler, J.B.T.; Sánchez-Romero, F.-J.; Ferrer-Gisbert, P.S.; Gozálvez, J.J.F.; Gisbert, C.M.F. Theoretical and experimental analysis of a floating photovoltaic cover for water irrigation reservoirs. Energy 2014, 67, 246-255. [CrossRef]

24. Bailey, I.G.; Darkal, H. (Not) talking about justice: Justice self-recognition and the integration of energy and environmental-social justice into renewable energy siting. Local Environ. 2017, 23, 335-351. [CrossRef]

25. Nerini, F.F.; Tomei, J.; To, L.S.; Bisaga, I.; Parikh, P.; Black, M.; Borrion, A.; Spataru, C.; Broto, V.C.; Anandarajah, G.; et al. Mapping synergies and trade-offs between energy and the Sustainable Development Goals. Nat. Energy 2017, 3, 10-15. [CrossRef]

26. Trainor, A.M.; McDonald, R.I.; Fargione, J. Energy Sprawl Is the Largest Driver of Land Use Change in United States. PLoS ONE 2016, 11, e0162269. [CrossRef] [PubMed]

27. Harvey, M.; Pilgrim, S. The new competition for land: Food, energy, and climate change. Food Policy 2011, 36, S40-S51. [CrossRef]

28. Choi, C.S.; Siregar, I.Z.; Ravi, S. Reframing the Competition for Land between Food and Energy Production in Indonesia. In Land Cover and Land Use Change on Islands: Social \& Ecological Threats to Sustainability; Walsh, S.J., Riveros-Iregui, D., Arce-Nazario, J., Page, P.H., Eds.; Springer International Publishing: New York, NY, USA, 2020; pp. 241-260. [CrossRef] 
29. Hargreaves, J. Pond Mixing; Southern Regional Aquaculture Center. 2003. Available online: http://aquaculture.ca.uky.edu/sites/aquaculture.ca.uky.edu/files/srac_4602_pond_mixing.pdf (accessed on 7 July 2020).

30. Oberle, M.; Salomon, S.; Ehrmaier, B.; Richter, P.; Lebert, M.; Strauch, S.M. Diurnal stratification of oxygen in shallow aquaculture ponds in central Europe and recommendations for optimal aeration. Aquaculture 2019, 501, 482-487. [CrossRef]

31. Lazur, A.M.; Britt, D.C. Pond Recirculating Production Systems; Southern Regional Aquaculture Center. 1997. Available online: http://fisheries.tamu.edu/files/2013/09/SRAC-Publication-No.-455-Pond-RecirculatingProduction-Systems.pdf (accessed on 8 July 2020).

32. Garrison, P.J.; Marshall, D.W.; Stremick-Thompson, L.; Cicero, P.L.; Dearlove, P.D. Effects of pier shading on littoral zone habitat and communities in Lakes Ripley and Rock, Jefferson County. Wis. Dep. Nat. Resour. 2005, PUB-SS-1006, 2-17.

33. Kallis, G. The EU water framework directive: Measures and implications. Hydrol. Res. 2001, 3, $125-142$. [CrossRef]

34. Wilhelm, J.A.; Smith, R.G. Ecosystem services and land sparing potential of urban and peri-urban agriculture: A review. Renew. Agric. Food Syst. 2017, 33, 481-494. [CrossRef]

35. Phalan, B. What Have We Learned from the Land Sparing-sharing Model? Sustainability 2018, 10, 1760. [CrossRef]

36. Macknick, J.; Beatty, B.; Hill, G. Overview of Opportunities for Co-Location of Solar Energy Technologies and Vegetation (NREL/TP-6A20-60240); National Renewable Energy Laboratory: Golden, CO, USA, 2013.

37. Walston, L.J.; Mishra, S.K.; Hartmann, H.M.; Hlohowskyj, I.; McCall, J.; Macknick, J. Examining the Potential for Agricultural Benefits from Pollinator Habitat at Solar Facilities in the United States. Environ. Sci. Technol. 2018, 52, 7566-7576. [CrossRef]

38. Hoffacker, M.K.; Allen, M.F.; Hernandez, R. Land-Sparing Opportunities for Solar Energy Development in Agricultural Landscapes: A Case Study of the Great Central Valley, CA, United States. Environ. Sci. Technol. 2017, 51, 14472-14482. [CrossRef]

39. Dubey, S.; Jadhav, N.Y.; Zakirova, B. Socio-economic and environmental impacts of silicon based photovoltaic (PV) technologies. Energy Procedia 2013, 33, 322-334. [CrossRef]

40. Fthenakis, V.; Kim, H.C. Land use and electricity generation: A life-cycle analysis. Renew. Sustain. Energy Rev. 2009, 13, 1465-1474. [CrossRef]

41. Horner, R.M.; Clark, C.E. Characterizing variability and reducing uncertainty in estimates of solar land use energy intensity. Renew. Sustain. Energy Rev. 2013, 23, 129-137. [CrossRef]

42. Ong, S.; Campbell, C.; Denholm, P.; Margolis, R.; Heath, G. Land-Use Requirements for Solar Power Plants in the United States (NREL/TP-6A20-56290); National Renewable Energy Laboratory (NREL): Golden, CO, USA, 2013.

43. Elliott-Fisk, D.L. Viticultural soils of California, with special reference to the Napa valley. J. Wine Res. 1993, 4, 67-77. [CrossRef]

44. Severy, C.L.; Thompson, R.M. Coalmont Area, Jackon County, Colorado; Wyoming Geological Association. 1953. Available online: http://archives.datapages.com/data/wga/data/008/008001/139_wga0080139.htm (accessed on 10 July 2020).

45. PRISM Climate Group. Oregon State University. Available online: http://prism.oregonstate.edu (accessed on 2 April 2020).

46. PRISM Descriptions of $\{$ PRISM $\}$ spatial climate datasets for the conterminous United States. Available online: https://prism.oregonstate.edu/documents/PRISM_datasets.pdf (accessed on 2 April 2020).

47. Sharp Electronics Corporation. Sharp Multi-purpose Module \{ND\}-208U2. Available online: https: //www.altestore.com/static/datafiles/Others/Sharp_208U2.pdf (accessed on 8 July 2020).

48. Risen Energy. Risen Solar Technology: High performance Monocrystalline Perc Module: \{RSM\} 144-6-360M-380M/5BB. Available online: https:/en.risenenergy.com/uploadfile/201808/215504a664.pdf (accessed on 7 July 2020).

49. Jinko Solar. Eagle 1500V 72 340-360 Watt \{MonoCrystalline\} Module. Available online: http://jinkosolar.com. au/wp-content/uploads/2019/03/Eagle-JKM340-360M-72H-V-A2-EN.pdf (accessed on 8 July 2020).

50. ReneSola Ltd. Virtus $囚\{$ II $\}$ Module: 305W/310W/315W/320W. Available online: http://www.renesola.com/ file/Global/product/pdf/Virtus\%20II\%20305-320(4035)\%204BB\%201000V\%20US\%201606.pdf (accessed on 6 July 2020). 
51. Bartle, C.; Harter, S. Webinar- Kelseyville Wastewater Treatment Plant. Available online: https://betterbuildingssolutioncenter.energy.gov/sites/default/files/tools/Floating\%20Solar\%20C\&T_ DOE\%20Webinar_CB_032219.pptx\%203\%202019.pdf (accessed on 22 June 2020).

52. Kunii, H.; Maeda, K. Seasonal and long-term changes in surface cover of aquatic plants in a shallow pond, Ojaga-ike, Chiba, Japan. Hydrobiologia 1982, 87, 45-55. [CrossRef]

53. Tanny, J.; Cohen, S.; Berger, D.; Teltch, B.; Mekhmandarov, Y.; Bahar, M.; Katul, G.; Assouline, S. Evaporation from a reservoir with fluctuating water level: Correcting for limited fetch. J. Hydrol. 2011, 404, 146-156. [CrossRef]

54. Wirth, M.A. Shape Analysis and Measurement. Ph.D. Thesis, University of Guelph Computing and Information Science Image Processing Group, Guelph, ON, Canada, 2001.

55. Harrington, S.; Teitelman, J.; Rummel, E.; Morse, B.; Chen, P.; Eisentraut, D.; McDonough, D. Validating Google Earth Pro as a Scientific Utility for Use in Accident Reconstruction. SAE Int. J. Transp. Saf. 2017, 5, 135-166. [CrossRef]

56. Johnson Controls. Personal communication. 2020.

57. Ciel et Terre. Available online: https://www.ciel-et-terre.net/ (accessed on 31 August 2020).

58. Santangeli, A.; Toivonen, T.; Pouzols, F.M.; Pogson, M.; Hastings, A.; Smith, P.; Moilanen, A. Global change synergies and trade-offs between renewable energy and biodiversity. GCB Bioenergy 2015, 8, 941-951. [CrossRef]

59. Geels, F.W.; Schot, J. Typology of sociotechnical transition pathways. Res. Policy 2007, 36, 399-417. [CrossRef]

60. Fuso Nerini, F.; Sovacool, B.; Hughes, N.; Cozzi, L.; Cosgrave, E.; Howells, M.; Tavoni, M.; Tomei, J.; Zerriffi, H.; Milligan, B. Connecting climate action with other Sustainable Development Goals. Nat. Sustain. 2019, 2, 674-680. [CrossRef]

61. Battaglia, C.; Cuevas, A.; De Wolf, S. High-efficiency crystalline silicon solar cells: Status and perspectives. Energy Environ. Sci. 2016, 9, 1552-1576. [CrossRef]

62. Lee, N.; Grunwald, U.; Rosenlieb, E.; Mirletz, H.; Aznar, A.; Spencer, R.; Cox, S. Hybrid floating solar photovoltaics-hydropower systems: Benefits and global assessment of technical potential. Renew. Energy 2020, 162, 1415-1427. [CrossRef]

63. Liber, W.; Bartle, C.; Spencer, R.; Jordan, M.; Cagle, A.E.; Lewis, T. Statewide Potential Study for the Implementation of Floating Solar Photovoltaic Arrays; Colorado Energy Office: Denver, CO, USA, 2019.

64. Farfan, J.; Breyer, C. Combining Floating Solar Photovoltaic Power Plants and Hydropower Reservoirs: A Virtual Battery of Great Global Potential. Energy Procedia 2018, 155, 403-441. [CrossRef]

65. Gitau, P.; Ndiritu, G.; Gichuki, N. Ecological, recreational and educational potential of a small artificial wetland in an urban environment. Afr. J. Aquat. Sci. 2019, 44, 329-338. [CrossRef]

66. Shepherd, N.L.; Nairn, R. Metals retention in a net alkaline mine drainage impacted stream due to the colonization of the North American Beaver (Castor canadensis). Sci. Total. Environ. 2020, 731, 139203. [CrossRef]

67. Wu, J.S.; Holman, R.E.; Dorney, J.R. Systematic Evaluation of Pollutant Removal by Urban Wet Detention Ponds. J. Environ. Eng. 1996, 122, 983-988. [CrossRef]

68. Cole, J.J.; Prairie, Y.T.; Caraco, N.F.; McDowell, W.H.; Tranvik, L.J.; Striegl, R.G.; Duarte, C.M.; Kortelainen, P.; Downing, J.A.; Middelburg, J.J.; et al. Plumbing the Global Carbon Cycle: Integrating Inland Waters into the Terrestrial Carbon Budget. Ecosystems 2007, 10, 172-185. [CrossRef]

69. Raymond, P.A.; Hartman, J.; Lauerwald, R.; Sobek, S.; McDonald, C.P.; Hoover, M.; Butman, D.; Striegl, R.; Mayorga, E.; Humborg, C.; et al. Global carbon dioxide emissions from inland waters. Nature 2013, 503, 355-359. [CrossRef]

70. Lehner, B.; Liermann, C.R.; Revenga, C.; Vörösmarty, C.; Fekete, B.; Crouzet, P.; Döll, P.; Endejan, M.; Frenken, K.; Magome, J.; et al. High-resolution mapping of the world's reservoirs and dams for sustainable river-flow management. Front. Ecol. Environ. 2011, 9, 494-502. [CrossRef]

71. Downing, J.A.; Prairie, Y.T.; Cole, J.J.; Duarte, C.M.; Tranvik, L.J.; Striegl, R.G.; McDowell, W.H.; Kortelainen, P.; Caraco, N.F.; Melack, J.M. The global abundance and size distribution of lakes, ponds, and impoundments. Limnol. Oceanogr. 2006, 51, 2388-2397. [CrossRef]

72. Downing, J.A. Emerging global role of small lakes and ponds: Little things mean a lot. Limnetica 2010, 29, 0009-0024. 
73. Léonard, R.; Legendre, P.; Jean, M.; Bouchard, A. Using the landscape morphometric context to resolve spatial patterns of submerged macrophyte communities in a fluvial lake. Landsc. Ecol. 2007, 23, 91-105. [CrossRef]

74. Sassolas-Serrayet, T.; Cattin, R.; Ferry, M. The shape of watersheds. Nat. Commun. 2018, 9, 3791. [CrossRef]

75. Amiri, B.J.; Baheri, B.; Fohrer, N.; Adamowski, J.F. Regionalization of flood magnitudes using the ecological attributes of watersheds. Geocarto Int. 2019, 35, 917-933. [CrossRef]

76. Eadie, J.M.; Keast, A. Resource heterogeneity and fish species diversity in lakes. Can. J. Zool. 1984, 62, 1689-1695. [CrossRef]

77. Fuentes-Rodríguez, F.; Juan, M.; Gallego, I.; Lusi, M.; Fenoy, E.; Leon, D.; Peñalver, P.; Toja, J.; Casas, J.J. Diversity in Mediterranean farm ponds: Trade-offs and synergies between irrigation modernisation and biodiversity conservation. Freshw. Boil. 2012, 58, 63-78. [CrossRef]

78. Steele, M.K.; Heffernan, J.B. Morphological characteristics of urban water bodies: Mechanisms of change and implications for ecosystem function. Ecol. Appl. 2014, 24, 1070-1084. [CrossRef]

79. Krivtsov, V.; Birkinshaw, S.; Arthur, S.; Knott, D.; Monfries, R.; Wilson, K.; Christie, D.; Chamberlain, D.; Brownless, P.; Kelly, D.; et al. Flood resilience, amenity and biodiversity benefits of an historic urban pond. Philos. Trans. R. Soc. 2020, 378, 20190389. [CrossRef]

80. Song, K.; Xenopoulos, M.A.; Buttle, J.M.; Marsalek, J.; Wagner, N.D.; Pick, F.R.; Frost, P.C. Thermal stratification patterns in urban ponds and their relationships with vertical nutrient gradients. J. Environ. Manag. 2013, 127, 317-323. [CrossRef] [PubMed]

81. Gao, H.; Bohn, T.J.; Podest, E.; McDonald, K.C.; Lettenmaier, D.P. On the causes of the shrinking of Lake Chad. Environ. Res. Lett. 2011, 6, 034021. [CrossRef]

82. Huang, L.; Liu, J.; Shao, Q.; Liu, R. Changing inland lakes responding to climate warming in Northeastern Tibetan Plateau. Clim. Chang. 2011, 109, 479-502. [CrossRef]

83. Wurtsbaugh, W.A.; Miller, C.; Null, S.E.; Derose, R.J.; Wilcock, P.; Hahnenberger, M.; Howe, F.; Moore, J. Decline of the world's saline lakes. Nat. Geosci. 2017, 10, 816-821. [CrossRef]

84. De Anda, J.; Díaz-Torres, J.D.J.; Gradilla-Hernández, M.S.; De La Torre-Castro, L.M. Morphometric and water quality features of Lake Cajititlán, Mexico. Environ. Monit. Assess. 2019, 191, 92. [CrossRef] [PubMed]

85. Jones, B.A.; Fleck, J. Shrinking lakes, air pollution, and human health: Evidence from California's Salton Sea. Sci. Total. Environ. 2020, 712, 136490. [CrossRef] [PubMed]

86. Ho, J.C.; Michalak, A.M.; Pahlevan, N. Widespread global increase in intense lake phytoplankton blooms since the 1980s. Nature 2019, 574, 667-670. [CrossRef]

87. Ribeiro, A.E.D.; Arouca, M.C.; Coelho, D.M. Electric energy generation from small-scale solar and wind power in Brazil: The influence of location, area and shape. Renew. Energy 2016, 85, 554-563. [CrossRef]

88. Bordas, A. Windsor plans to use floating solar panel system to power town's public water facilities. 2019. in press. Available online: https://www.pressdemocrat.com/article/news/windsor-plans-to-use-floating-solarpanel-system-to-power-towns-public-wat/ (accessed on 14 July 2020).

89. Flynn, D.F.B.; Gogol-Prokurat, M.; Nogeire, T.; Molinari, N.; Richers, B.T.; Lin, B.; Simpson, N.; Mayfield, M.M.; Declerck, F. Loss of functional diversity under land use intensification across multiple taxa. Ecol. Lett. 2009, 12, 22-33. [CrossRef]

90. Drummond, M.A.; Loveland, T.R. Land-use Pressure and a Transition to Forest-cover Loss in the Eastern United States. Bioscience 2010, 60, 286-298. [CrossRef]

91. Brovkin, V.; Boysen, L.; Arora, V.K.; Boisier, J.P.; Cadule, P.; Chini, L.; Claussen, M.; Friedlingstein, P.; Gayler, V.; Hurk, B.J.J.M.V.D.; et al. Effect of Anthropogenic Land-Use and Land-Cover Changes on Climate and Land Carbon Storage in CMIP5 Projections for the Twenty-First Century. J. Clim. 2013, 26, 6859-6881. [CrossRef]

92. Bryden, J. Renewable Energy as a Rural Development Opportunity; NILF Discussion Papers: Oslo, Norway, 2010.

93. Capellán, I.; De Castro, C.; Arto, I. Assessing vulnerabilities and limits in the transition to renewable energies: Land requirements under 100\% solar energy scenarios. Renew. Sustain. Energy Rev. 2017, 77, 760-782. [CrossRef]

94. Johnson Controls. Personal communications. 2020.

95. Mulvaney, D. Identifying the roots of Green Civil War over utility-scale solar energy projects on public lands across the American Southwest. J. Land Use Sci. 2017, 12, 493-515. [CrossRef]

96. Welton, S.; Eisen, J. Clean Energy Justice: Charting an Emerging Agenda. Harv. Environ. Law Rev. 2019, 43, 307. 
97. Parker, S.S.; Pauly, G.B.; Moore, J.; Fraga, N.S.; Knapp, J.J.; Principe, Z.; Brown, B.V.; Randall, J.M.; Cohen, B.S.; Wake, T.A. Adapting the bioblitz to meet conservation needs. Conserv. Boil. 2018, 32, 1007-1019. [CrossRef]

98. Murphy-Mariscal, M.; Grodsky, S.M.; Hernandez, R.R. Solar Energy Development and the Biosphere. In $A$ Comprehensive Guide to Solar Energy Systems; Academic Press: London, UK, 2018; pp. 391-405.

99. Silliman, B.R.; Bertness, M.D. Shoreline Development Drives Invasion of Phragmites australis and the Loss of Plant Diversity on New England Salt Marshes. Conserv. Biol. 2004, 18, 1424-1434. [CrossRef]

100. Sundblad, G.; Bergström, U. Shoreline development and degradation of coastal fish reproduction habitats. Ambio 2014, 43, 1020-1028. [CrossRef]

101. Garone, P. The Fall and Rise of the Wetlands of California's Great Central Valley; University of California Press: Oakland, CA, USA, 2020.

102. Alcott, B. Jevons' paradox. Ecol. Econ. 2005, 54, 9-21. [CrossRef]

103. Garcia, V.R.; Gaspart, F.; Kastner, T.; Meyfroidt, P. Agricultural intensification and land use change: Assessing country-level induced intensification, land sparing and rebound effect. Environ. Res. Lett. 2020, 15, 085007. [CrossRef]

104. Dupraz, C.; Marrou, H.; Talbot, G.; Dufour, L.; Nogier, A.; Ferard, Y. Combining solar photovoltaic panels and food crops for optimising land use: Towards new agrivoltaic schemes. Renew. Energy 2011, 36, 2725-2732. [CrossRef]

105. Amaducci, S.; Yin, X.; Colauzzi, M. Agrivoltaic systems to optimise land use for electric energy production. Appl. Energy 2018, 220, 545-561. [CrossRef]

106. Othman, M.N.A.; Hassan, R.; Harith, M.N.; Sah, A.S.R.M. Red Seaweed Gracilaria Arcuata in Cage Culture Area of Lawas, Sarawak. Borneo J. Resour. Sci. Technol. 2015, 5, 53-61. [CrossRef]

107. Bychkov, I.V.; Gagarinova, O.V.; Maksimova, I.I.; Bogdanov, V.N. Water Protection Zoning as an Instrument of Preservation for Lake Baikal. Water 2018, 10, 1474. [CrossRef]

108. Doris Group Hibernia. Available online: https:/www.dorisgroup.com/projets/hibernia/ (accessed on 9 August 2020).

109. Muehlenbachs, L.; Cohen, M.A.; Gerarden, T. The impact of water depth on safety and environmental performance in offshore oil and gas production. Energy Policy 2013, 55, 699-705. [CrossRef]

110. Phillips, M.; Subasinghe, R.P.; Tran, N.; Kassam, L.; Chan, C.Y. Aquaculture Big Numbers; Food and Agriculture Organization of the United Nations: Rome, Italy, 2016.

111. Lovering, J.; Swain, M.; Blomqvist, L.; Hernandez, R.R. Land-use intensity of electricity production and tomorrow's energy landscape. status (unpublished; manuscript in preparation).

112. Cagle, A.; Hernandez, R.R.; Shepherd, M.; Cagle, A.; Hernandez, R.R.; Shepherd, M. Solar Energy Development in an Era of Looming Land Scarcity: Land-Use Metric Standardization and Novel Concepts. AGUFM 2019, 2019, GC53I-1206.

113. Koho, M.; Torvinen, S.; Romiguer, A.T. Objectives, enablers and challenges of sustainable development and sustainable manufacturing: Views and opinions of Spanish companies. In Proceedings of the 2011 IEEE International Symposium on Assembly and Manufacturing (ISAM), Tampere, Finland, 25-27 May 2011.

114. Lausch, A.; Blaschke, T.; Haase, D.; Herzog, F.; Syrbe, R.-U.; Tischendorf, L.; Walz, U. Understanding and quantifying landscape structure - A review on relevant process characteristics, data models and landscape metrics. Ecol. Model. 2015, 295, 31-41. [CrossRef]

115. Grubert, E.; Rogers, E.; Sanders, K.T. Consistent Terminology and Reporting Are Needed to Describe Water Quantity Use. J. Water Resour. Plan. Manag. 2020, 146, 04020064. [CrossRef]

116. DeFries, R.S.; Fanzo, J.; Remans, R.; Palm, C.; Wood, S.A.; Anderman, T.L. Metrics for land-scarce agriculture. Science 2015, 349, 238-240. [CrossRef]

117. Google Earth Pro v 7.3.2.5776 (64-bit). Windsor, California. 38 $32^{\prime} 22.09^{\prime \prime} \mathrm{N} 122^{\circ} 48^{\prime} 52.5^{\prime \prime} \mathrm{W}$ elev. $92 \mathrm{ft}$. eye alt 1,413ft. CNES/Airbus 2020. (11/7/2019). Available online: https://earth.google.com/ (accessed on 13 April 2020).

118. Google Earth Pro v 7.3.2.5776 (64-bit). Windsor, California. $38^{\circ} 32^{\prime} 22.09^{\prime \prime} \mathrm{N} 122^{\circ} 48^{\prime} 52.5^{\prime \prime} \mathrm{W}$ elev. $92 \mathrm{ft}$. eye alt 1,413ft. Maxar Technologies 2020. (3/28/2018). Available online: https://earth.google.com/ (accessed on 13 April 2020).

119. Google Earth Pro v 7.3.2.5776 (64-bit). Windsor, California. $38^{\circ} 32^{\prime} 22.09^{\prime \prime} \mathrm{N} 122^{\circ} 48^{\prime} 52.5^{\prime \prime} \mathrm{W}$ elev. $92 \mathrm{ft}$. eye alt 1,413ft. Maxar Technologies 2020. (7/28/2019). Available online: https://earth.google.com/ (accessed on 13 April 2020). 
120. Google Earth Pro v 7.3.2.5776 (64-bit). Windsor, California. $38^{\circ} 32^{\prime} 22.09^{\prime \prime} \mathrm{N} 122^{\circ} 48^{\prime} 52.5^{\prime \prime} \mathrm{W}$ elev. $92 \mathrm{ft}$. eye alt 1,413ft. Maxar Technologies 2020. (10/23/2019). Available online: https://earth.google.com/ (accessed on 13 April 2020).

121. Google Earth Pro v 7.3.2.5776 (64-bit). Oakville, California. $38^{\circ} 25^{\prime} 18.16^{\prime \prime} \mathrm{N} 122^{\circ} 24^{\prime} 31.40^{\prime \prime} \mathrm{W}$ elev $216 \mathrm{ft}$. eye alt 1,139 ft. Maxar Technologies 2020. (9/1/2018). Available online: https://earth.google.com/ (accessed on 13 April 2020).

122. Google Earth Pro v 7.3.2.5776 (64-bit). Oakville, California. $38^{\circ} 25^{\prime} 18.16^{\prime \prime} \mathrm{N} 122^{\circ} 24^{\prime} 31.40^{\prime \prime} \mathrm{W}$ elev $216 \mathrm{ft}$. eye alt 1,139 ft. Maxar Technologies 2020. (2/5/2018). Available online: https://earth.google.com/ (accessed on 13 April 2020).

123. Google Earth Pro v 7.3.2.5776 (64-bit). Oakville, California. $38^{\circ} 25^{\prime} 18.16^{\prime \prime} \mathrm{N} 122^{\circ} 24^{\prime} 31.40^{\prime \prime} \mathrm{W}$ elev $216 \mathrm{ft}$. eye alt 1,139 ft. Maxar Technologies 2020. (3/16/2016). Available online: https://earth.google.com/ (accessed on 13 April 2020).

124. Google Earth Pro v 7.3.2.5776 (64-bit). Oakville, California. $38^{\circ} 25^{\prime} 18.16^{\prime \prime} \mathrm{N} 122^{\circ} 24^{\prime} 31.40^{\prime \prime} \mathrm{W}$ elev $216 \mathrm{ft}$. eye alt 1,139 ft. Maxar Technologies 2020. (5/20/2017). Available online: https://earth.google.com/ (accessed on 13 April 2020).

125. Google Earth Pro v 7.3.2.5776 (64-bit). Orlando, Florida. $28^{\circ} 30^{\prime} 08.67^{\prime \prime} \mathrm{N} 81^{\circ} 25^{\prime} 18.15^{\prime \prime} \mathrm{W}$. elev $103 \mathrm{ft}$. eye alt 1,401ft. Landsat/Copernicus 2020. (12/17/2018). Available online: https://earth.google.com/ (accessed on 13 April 2020).

126. Google Earth Pro v 7.3.2.5776 (64-bit). Orlando, Florida. $28^{\circ} 30^{\prime} 08.67^{\prime \prime} \mathrm{N} 81^{\circ} 25^{\prime} 18.15^{\prime \prime} \mathrm{W}$. elev $103 \mathrm{ft}$. eye alt 1,401ft. Maxar Technologies 2020. (5/8/2016). Available online: https://earth.google.com/ (accessed on 13 April 2020).

127. Google Earth Pro v 7.3.2.5776 (64-bit). Orlando, Florida. $28^{\circ} 30^{\prime} 08.67^{\prime \prime} \mathrm{N} 81^{\circ} 25^{\prime} 18.15^{\prime \prime} \mathrm{W}$. elev $103 \mathrm{ft}$. eye alt 1,401ft. Landsat/Copernicus 2020. (5/6/2017). Available online: https://earth.google.com/ (accessed on 13 April 2020).

128. Google Earth Pro v 7.3.2.5776 (64-bit). Orlando, Florida. $28^{\circ} 30^{\prime} 08.67^{\prime \prime} \mathrm{N} 81^{\circ} 25^{\prime} 18.15^{\prime \prime} \mathrm{W}$. elev $103 \mathrm{ft}$. eye alt 1,401ft. Landsat/Copernicus 2020. (1/3/2018). Available online: https://earth.google.com/ (accessed on 13 April 2020).

129. Google Earth Pro v 7.3.2.5776 (64-bit). Walden, Colorado. $40^{\circ} 44^{\prime \prime} 24.70^{\prime \prime} \mathrm{N} 106^{\circ} 16^{\prime} 50.82^{\prime \prime} \mathrm{W}$. elev 8,065. eye alt 8,349ft. Landsat/Copernicus 2020. (9/7/2016). Available online: https://earth.google.com/ (accessed on 13 April 2020).

130. Google Earth Pro v 7.3.2.5776 (64-bit). Walden, Colorado. $40^{\circ} 44^{\prime \prime} 24.70^{\prime \prime} \mathrm{N} 106^{\circ} 16^{\prime} 50.82^{\prime \prime} \mathrm{W}$. elev 8,065. eye alt 8,349ft. Landsat/Copernicus 2020. (8/26/2019). Available online: https://earth.google.com/ (accessed on 13 April 2020).

131. Google Earth Pro v 7.3.2.5776 (64-bit). Walden, Colorado. $40^{\circ} 44^{\prime \prime} 24.70^{\prime \prime} \mathrm{N} 106^{\circ} 16^{\prime} 50.82^{\prime \prime} \mathrm{W}$. elev 8,065. eye alt 8,349ft. Maxar Technologies 2020. (9/17/2015). Available online: https://earth.google.com/ (accessed on 13 April 2020).

132. Google Earth Pro v 7.3.2.5776 (64-bit). Walden, Colorado. $40^{\circ} 44^{\prime \prime} 24.70^{\prime \prime} \mathrm{N} 106^{\circ} 16^{\prime} 50.82^{\prime \prime} \mathrm{W}$. elev 8,065. eye alt 8,349ft. Landsat/Copernicus 2020. (6/18/2014). Available online: https://earth.google.com/ (accessed on 13 April 2020).

(C) 2020 by the authors. Licensee MDPI, Basel, Switzerland. This article is an open access article distributed under the terms and conditions of the Creative Commons Attribution (CC BY) license (http://creativecommons.org/licenses/by/4.0/). 